Review

\title{
Halophytic herbs of the Mediterranean basin: An alternative approach to health
}

\author{
S.A. Petropoulos ${ }^{\mathrm{a}, *}$, A. Karkanis ${ }^{\mathrm{a}}$, N. Martins ${ }^{\mathrm{b}}$, I.C.F.R. Ferreira ${ }^{\mathrm{b}, * *}$ \\ a Department of Agriculture Crop Production and Rural Environment, University of Thessaly, Fytokou Str, 38446 Nea Ionia, Magnesia, Greece \\ ${ }^{\mathrm{b}}$ Mountain Research Centre (CIMO), ESA, Polytechnic Institute of Bragança, Campus de Santa Apolónia, 1172, 5301-855 Bragança, Portugal
}

\section{A R T I C L E I N F O}

\section{Keywords:}

Bioactive compounds

Halophytes

Health effects

Native herbs

Salinity

Secondary metabolites

\begin{abstract}
A B S T R A C T
Wild native species are usually grown under severe and stressful conditions, while a special category includes halophytic species that are tolerant to high salinity levels. Native halophytes are valuable sources of bioactive molecules whose content is higher in saline than normal conditions, since the adaptation to salinity mechanisms involve apart from changes in physiological functions the biosynthesis of protectant molecules. These compounds include secondary metabolites with several beneficial health effects which have been known since ancient times and used for medicinal purposes. Recent trends in pharmaceutical industry suggest the use of natural compounds as alternative to synthetic ones, with native herbs being strong candidates for this purpose due to their increased and variable content in health promoting compounds. In this review, an introductory section about the importance of native herbs and halophyte species for traditional and modern medicine will be presented. A list of the most important halophytes of the Mediterranean basin will follow, with special focus on their chemical composition and their reported by clinical and ethnopharmacological studies health effects. The review concludes by suggesting future requirements and perspectives for further exploitation of these valuable species within the context of sustainability and climate change.
\end{abstract}

\section{Introduction}

The Mediterranean basin is abundant with native plants that have adapted to various unfavorable conditions such as high salinity, especially when considering the extensive coastline and the great number of islands. The adaptation of halophytic species to high salinity levels includes both morphological and physiological acclimatization features, while of special importance are the various defense mechanisms that plants have developed which involve the enhanced biosynthesis of primary and secondary metabolites (Ksouri et al., 2008). Halophytes have been traditionally used for food and medicinal purposes throughout the centuries, while nowadays there is a great research interest for their health promoting effects. Considering the recent trends in pharmaceutical industry for new natural compounds and the consumers' concerns about consumption of synthetic compounds and the health effects that these might have, there is an imperative need for using native herbs not only as food but also for medicinal formulations and therapeutic purposes.

The application of native cultivated and non-cultivated species in traditional and folk medicine used to be very common in developing countries for people who do not have access to conventional drugs and modern medicine, while nowadays it is a common place in both developing and developed countries for the treatment of mild illnesses such as coughs, stomach aches, headaches, fatigue etc. and the overall well-being. However, there is the misconception that all natural remedies and food supplements are safe and people seem to ignore safety issues regarding toxic effects of specific species due to antinutrients content, the recommended daily intake of specific compounds as well counter effects and interactions with conventional drugs or other bioactive compounds that have not been studied under long-term clinical studies (Kristanc and Kreft, 2016). Moreover, bioactive compounds content of wild species is affected by several factors such as genotype, growing conditions, harvest time and growth stage among others that make general recommendations for safe consumption and daily intakes very complex and controversial (Mukherjee et al., 2011). Sánchez-Mata et al. (2012) have also demonstrated the great diversity in chemical composition among the species as well the various ecotypes of native species of the Mediterranean basin due to the variety of climate and soil conditions and terrain morphology.

Due to these concerns and the great surge and consumers' demand

\footnotetext{
* Corresponding author. University of Thessaly, School of Agricultural Sciences, Fytokou Street, 38446 N. Ionia, Magnissia, Greece.

** Corresponding author.

E-mail addresses: spetropoulos@uth.gr (S.A. Petropoulos), iferreira@ipb.pt (I.C.F.R. Ferreira).
} 
for these botanical medicines, there has been an inducement for many research studies where the in vitro and in vivo health effects and therapeutic properties against various chronic diseases have been evaluated (Simopoulos, 2008, 2004; Trichopoulou et al., 2000; Vardavas et al., 2006). Moreover, many ethnopharmacological and ethnobotanical studies validate properties and uses of medicinal herbs that have been described since the ancient times by the scholars and are being imparted from generation to generation (González-Tejero et al., 2008; Ksouri et al., 2012; Pieroni, 2017).

Considering the surge for natural products and remedies of herbal origin, the aim of this review was to record and briefly describe the most important halophytic herbs of the Mediterranean basin with wellknown uses for medicinal and therapeutic purpose in traditional and folk medicine. Moreover focus will be given on their chemical composition and health effects with special interest in toxic effects and antinutrients compounds content. The most recent clinical and ethnopharmacological studies that confirm the so far alleged health promoting effects will be also highlighted, while the involved mechanisms for these therapeutic effects will be described. The review concludes by suggesting future requirements and perspectives for further exploitation of these valuable species within the context of sustainability and halophyte agriculture under climate change conditions as well as bioconservation of wild medicinal halophytes.

\section{Medicinal halophytes}

In the following section the most common halophytes of the Mediterranean basin will be presented focusing on their medicinal uses. The reported species have multiple medicinal uses and therapeutic properties with various plant parts being used, as presented in Table 1 . Moreover, in Tables 2 and 3 the phenolic compounds content and the confirmed bioactive properties for each species are presented, respectively.

\subsection{Asplenium ceterach $L$.}

\subsubsection{Botanical aspects}

Scale fern [Asplenium ceterach L. (syn. Ceterach officinarum Willd)] is a perennial rhizomatous herb that belongs to Aspleniaceae family (Durdević et al., 2007; Van Den Heede et al., 2004). Apart from its roots, the rest of the plant is used for medicinal purposes in several Mediterranean countries (González-Tejero et al., 2008; Pieroni et al., 2004), while according to Bogdanović et al. (2011) plants grown in half-strength MS media are able to tolerate 50 and $100 \mathrm{mM}$ of $\mathrm{NaCl}$. In order to adapt to saline conditions plants increased the synthesis of phenolic compounds which serve as protectants against oxidative stress (Bogdanović et al., 2011).

\subsubsection{Chemical composition}

Scale fern presents a wide variety of chemical constituents, among them volatile organic compounds, such as lipid derivatives (77.4\%): nonanal, (E)-2-nonenal, (E)-2-heptenal, 1-octen-3-ol, tetradecanoic acid, hexahydrofarnesylacetone, (E)-2-tridecenoic acid); shikimic compounds (21.3\%): 3,4-dihydroxybenzaldehyde, 3-methoxy-4-hydroxybenzoic acid, 4-hydroxybenzoic acid, benzoic acid, 2-amino-4methoxyphenol; carotenoid derivatives $(0.8 \%)$ : 4-hydroxy- $\beta$-ionone, 3 hydroxy-5,6-epoxy- $\beta$-ionone (Froissard et al., 2015). Phenolic compounds, both flavonoids and phenolic acids are also present, but in lesser amounts, being chlorogenic and caffeic acids the most abundant ones. Kashyap et al. (2017) reported that $A$. ceterach is a good source of kaempferol derivatives, namely Kaempferol 3-(6-malonyl)-D-glucoside and Kaempferol 3-(6-malonyl)-D-galactoside, which are highly regarded as anticancer molecules. Moreover, according to Durdević et al. (2007) free and bound phenolics in leaves $\left(11744.00 \mathrm{\mu g} \mathrm{g}^{-1}\right.$ and of $9135.00 \mu \mathrm{g} \mathrm{g}^{-1}$, for free and bound phenolics, respectively) and rhizomes $\left(2811.11 \mu \mathrm{gg}^{-1}\right.$ and of $1962.74 \mu \mathrm{gg}^{-1}$, for free and bound

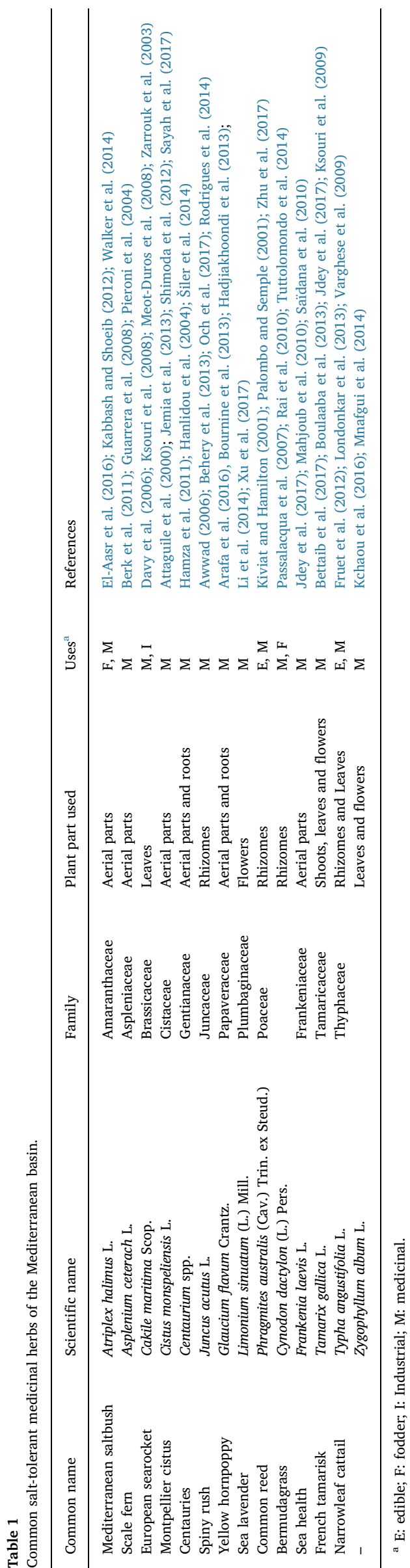


Table 2

Total phenolics content ${ }^{\mathrm{b}}$ of various salt tolerant medicinal plants native in the Mediterranean region.

\begin{tabular}{|c|c|c|c|}
\hline Scientific name & Plant parts & $\begin{array}{l}\text { Total Phenolics } \\
\text { (mg GAE/g } \\
\text { extract) }\end{array}$ & References \\
\hline Asplenium ceterach L. & $\begin{array}{l}\text { Leaves } \\
\text { Rhizomes }\end{array}$ & $\begin{array}{l}11.74 \\
2.81\end{array}$ & Durdević et al. (2007) \\
\hline Atriplex halimus L. & $\begin{array}{l}\text { Leaves } \\
\text { Stems }\end{array}$ & $\begin{array}{l}10.12 \\
3.77\end{array}$ & $\begin{array}{l}\text { Benhammou et al. } \\
\text { (2009) }\end{array}$ \\
\hline Cakile maritima Scop. & Leaves & $\begin{array}{l}22.24 \\
31.58-66.93\end{array}$ & $\begin{array}{l}\text { Meot-Duros et al. } \\
\text { (2008) } \\
\text { Ksouri et al. (2007) }\end{array}$ \\
\hline $\begin{array}{l}\text { Cynodon dactylon (L.) } \\
\text { Pers. }\end{array}$ & Rhizomes & 39.82 & Soraya et al. (2015) \\
\hline Frankenia laevis L. & Leaves & 253 & Lopes et al. (2016) \\
\hline Juncus acutus L. & - & $17-93$ & $\begin{array}{l}\text { Rodrigues et al. } \\
\text { (2014) }\end{array}$ \\
\hline $\begin{array}{l}\text { Limonium sinuatum (L.) } \\
\quad \text { Mill. }\end{array}$ & Flowers & 34.17 & Li et al. (2014) \\
\hline Tamarix gallica L. & $\begin{array}{l}\text { Leaves } \\
\text { Flowers }\end{array}$ & $\begin{array}{l}3.91 \\
12.33\end{array}$ & $\begin{array}{l}\text { Ksouri et al. (2009) } \\
\text { Ksouri et al. (2009) }\end{array}$ \\
\hline Zygophyllum album L. & Leaves & $78.0-403.4$ & Kchaou et al. (2016) \\
\hline
\end{tabular}

a Total phenolic content is expressed as gallic acid (GAE) equivalents (mg gallic acid $\mathrm{g}^{-1}$ dry weight (DW)).

b Total phenolic compounds as determined by LC-DAD-ESI/MS.

phenolics, respectively) of $A$. ceterach were significantly higher than other species of the genus. Also interesting to highlight is that a pronounced decrease in phenolic compounds content is observed during dehydration process due to increased activity of peroxidase (POD) and polyphenol oxidase (PPO) enzymes (Živković et al., 2010).

\subsubsection{Health effects}

Asplenium ceterach presents a very interesting antioxidant potential, namely acting as free radicals scavenger, reducing and chelating agent, and even DNA damage protector (Berk et al., 2011), while GonzálezTejero et al. (2008) reported its use for the treatment of disorders related to the respiratory system and intestinal. It also exhibits significant antimicrobial effects, namely against the most common Gram-positive microorganisms, among them Shigella dysenteriae and Staphylococcus aureus species (Berk et al., 2011). Besides to these effects, very important demulcent, expectorant, laxative, diuretic, anticatarrhal, anthelmintic and even emmenagogue properties have been reported, being mostly of these effects directly attributed to its high content in phenolic compounds (Berk et al., 2011; Froissard et al., 2015; Guarrera et al., 2008; Pieroni, 2017), while ethnopharmacological studies have suggested the use of decoctions against menstrual pains, hypertension, joint aches, malaria, renal colics and kidney stone formation (Maria et al., 2005; Passalacqua et al., 2007).

Despite of the species belonging to the group of ferns which may exhibit toxic effects, no toxicity has been reported for Asplenium caterach L. so far.

\subsection{Atriplex halimus $L$.}

\subsubsection{Botanical aspects}

Also known as Mediterranean saltbush, Atriplex halimus L. is a euhalophyte native in the broad Mediterranean region usually used as a fodder or for medicinal purposes (Walker et al., 2014). According to Boughalleb et al. (2009) and Bendaly et al. (2016), low to moderate salinity had a stimulating effect on plant growth mainly due to promoting root and stem growth, while the salt tolerance could be attributed to compartmentalization of high amounts of $\mathrm{Na}^{+}$, the

Table 3

Biological activity of the selected medicinal halophytes and their main bioactive compounds.

\begin{tabular}{|c|c|c|c|}
\hline Scientific name & Biological activity & Bioactive compounds & References \\
\hline Asplenium ceterach $\mathrm{L}$. & $\begin{array}{l}\text { Antioxidant; Antimicrobial; Demulcent; } \\
\text { Expectorant; Laxative; Emmenagogue; Anticancer }\end{array}$ & $\begin{array}{l}\text { Kaempferol 3-(6-malonyl)-D-glucoside; } \\
\text { Kaempferol 3-(6-malonyl)-D-galactoside; } \\
\text { Chlorogenic acid; Caffeic acid }\end{array}$ & $\begin{array}{l}\text { Berk et al. (2011); Froissard et al. (2015); } \\
\text { Guarrera et al. (2008); Passalacqua et al. } \\
\text { (2007); Pieroni (2017) }\end{array}$ \\
\hline Atriplex halimus L. & $\begin{array}{l}\text { Antioxidant; Anti-leishmanial; Anti-multidrug } \\
\text { resistance; Cytotoxic; Antimicrobial; } \\
\text { Immunomodulatory; Anticancer }\end{array}$ & $\begin{array}{l}\text { Syringetin derivatives; Atriplexoside A; } \\
\text { Atriplexoside B; }\end{array}$ & $\begin{array}{l}\text { El-Aasr et al. (2016); Kabbash and Shoeib } \\
\text { (2012); Walker et al. (2014) }\end{array}$ \\
\hline Cakile maritima Scop. & $\begin{array}{l}\text { Antioxidant; Antibacterial; Antiscorbutic; Diuretic; } \\
\text { Digestive; Molluscicidal }\end{array}$ & Glucosinolates; Isothiocyanates & $\begin{array}{l}\text { Davy et al. (2006); Ksouri et al. (2012); Meot- } \\
\text { Duros et al. (2008); Radwan et al. (2008) }\end{array}$ \\
\hline Centaurium spp. & $\begin{array}{l}\text { Antioxidant, Antidiabetic, Antiflatulent, } \\
\text { Antipyretic, Antibacterial, Antifungal, Diuretic, } \\
\text { Digestive }\end{array}$ & Secoiridoid glycosides; Xanthones & $\begin{array}{l}\text { Đorđević et al. (2017); González-Tejero et al. } \\
\text { (2008); Pieroni et al. (2004); Šiler et al. } \\
\text { (2014); Valentāo et al. (2002) }\end{array}$ \\
\hline Cistus monspeliensis L. & $\begin{array}{l}\text { Antioxidant, Anti-inflammatory, Antibacterial, } \\
\text { Antiproliferative, Cytotoxic }\end{array}$ & $\begin{array}{l}\text { Terpenes; Carvacrol; Eugenol; Apigenin } \\
\text { diglucoside; Phenolic acid derivatives }\end{array}$ & $\begin{array}{l}\text { Barrajón-Catalán et al. (2011); Jemia et al. } \\
\text { (2013); Loizzo et al. (2013); Papaefthimiou } \\
\text { et al. (2014) }\end{array}$ \\
\hline Cynodon dactylon L. & $\begin{array}{l}\text { Anti-inflammatory, Diuretic, Antiemetic, } \\
\text { Antidiabetic, Angiogenic, Wound healing, } \\
\text { Antibacterial }\end{array}$ & Flavonoids; Carotenoids; Phytostilbenes & $\begin{array}{l}\text { Marasini et al. (2015); Rai et al. (2010); } \\
\text { Soraya et al. (2015); Tuttolomondo et al. } \\
\text { (2014); }\end{array}$ \\
\hline Frankenia laevis $\mathrm{L}$. & Antioxidant, Anti-tyrosinase, Antimicrobial & $\begin{array}{l}\text { Chlorogenic acid; Catechin; Volatile } \\
\text { compounds }\end{array}$ & $\begin{array}{l}\text { Hussein (2004a,b); Jdey et al. (2017); } \\
\text { Mahjoub et al. (2010) }\end{array}$ \\
\hline Glaucium flavum Crantz. & $\begin{array}{l}\text { Anti-inflammatory, Analgesic, Antibacterial, } \\
\text { Antifungal, Anticancer, Cytotoxic }\end{array}$ & Alkaloids & $\begin{array}{l}\text { Arafa et al. (2016); Bournine et al. (2013); } \\
\text { Hadjiakhoondi et al. (2013); Och et al. (2017) }\end{array}$ \\
\hline Juncus acutus L. & Antioxidant, Anti-acetylcholinesterase, Cytotoxic & $\begin{array}{l}\text { Phenanthrenoids; Coumarines; Carotenoids; } \\
\text { Juncunol }\end{array}$ & $\begin{array}{l}\text { Awwad (2006); Behery et al. (2013); } \\
\text { Rodrigues et al. (2017) }\end{array}$ \\
\hline $\begin{array}{l}\text { Limonium sinuatum (L.) } \\
\quad \text { Mill. }\end{array}$ & Antioxidant & Phenolic acids; Flavonoids & Li et al. (2014); Xu et al. (2017) \\
\hline $\begin{array}{l}\text { Phragmites australis (Cav.) } \\
\text { Trin. ex Steud. }\end{array}$ & Antioxidant, Anti-melanogensis, Hepatoprotective & Phenolic compounds & $\begin{array}{l}\text { Chen et al. (2013); Kiviat and Hamilton } \\
\text { (2001); Sim et al. (2017); Zhu et al. (2017) }\end{array}$ \\
\hline Tamarix gallica $\mathrm{L}$. & $\begin{array}{l}\text { Antioxidant, Anticancer, Anti-inflammatory, } \\
\text { Hepatotonic, Antimicrobial, Stimulant, Anti- } \\
\text { diarrheic; Antihyperlipidemic }\end{array}$ & $\begin{array}{l}\text { Phenolic acids; Flavonoids; Coumarins; } \\
\text { Tannins }\end{array}$ & $\begin{array}{l}\text { Boulaaba et al. (2015); Hmidene et al. (2017); } \\
\text { Ksouri et al. (2009); Lefahal et al. (2017); } \\
\text { Tomas-Barberán et al. (1990) }\end{array}$ \\
\hline Typha spp. & $\begin{array}{l}\text { Antioxidant, Antibacterial, Immunosuppressive; } \\
\text { Thrombolytic }\end{array}$ & $\begin{array}{l}\text { Flavonoids; Cerebrosides; Non-structural } \\
\text { carbohydrates }\end{array}$ & $\begin{array}{l}\text { Fruet et al. (2012); Londonkar et al. (2013); } \\
\text { Qin and Sun (2005); Varghese et al. (2009) }\end{array}$ \\
\hline Zyghophyllum album L. & $\begin{array}{l}\text { Antioxidant, Antidiabetic, Antibacterial, } \\
\text { Anticancer, Anti-inflammatory, Anti- } \\
\text { acetylcholinesterase }\end{array}$ & Flavonoids; Volatile compounds & $\begin{array}{l}\text { (Kchaou et al., 2016); Ksouri et al. (2013); } \\
\text { Mnafgui et al. (2014) }\end{array}$ \\
\hline
\end{tabular}


Atriplex halimus $\mathbf{L}$.

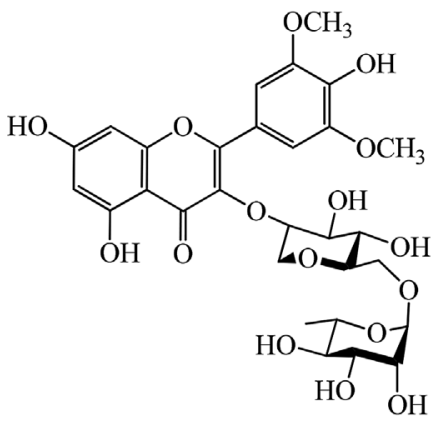

Syringetin 3-O- $B$-D-rutinoside

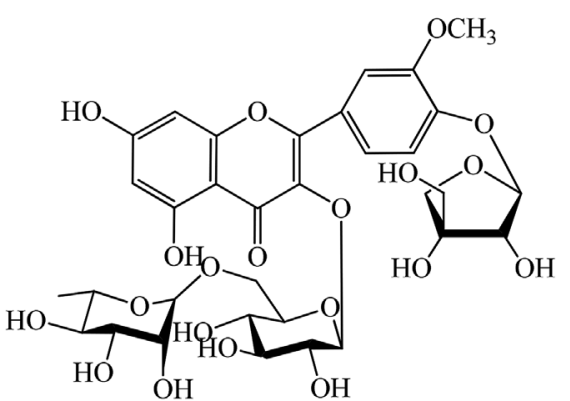

Atriplexoside A<smiles>COc1cc(-c2oc3cc(O)cc(O)c3c(=O)c2OC2OC3OOC(O)C(O)C(O)C(O)C3OC2O)cc(O)c1O</smiles>

Syringetin 3-O-B -D-glucopyranoside

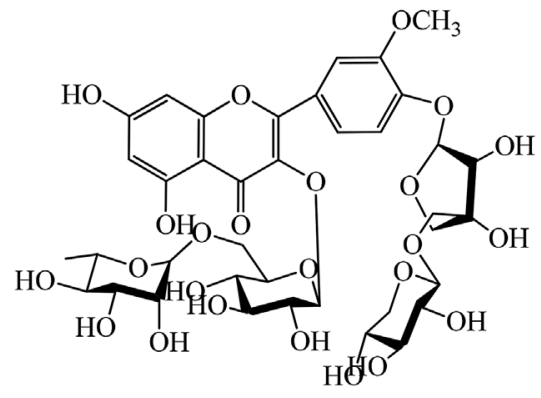

Atriplexoside B

Centaurium erythrea, $C$. maritimum<smiles>C=CC1C2=CCOC(=O)C2=CO[C@@H]1O[C@H]1O[C@H](CO)[C@@H](O)[C@H](O)[C@H]1O</smiles>

Gentiopicrin<smiles>C=C[C@@H]1C(CO)O[C@@H]2[C@H](O)[C@@H](O)C1OC=C1C(=O)OCC[C@@]12O</smiles>

Swertiamarin<smiles>C=C[C@H]1[C@H](O[C@@H]2O[C@H](CO)[C@@H](O)[C@H](O)[C@H]2O)OC=C2C(=O)OCC[C@]21C</smiles>

Sweroside<smiles>COc1cc(O)c2c(=O)c3c(OC)c(OC)c(OC)c(OC)c3oc2c1</smiles>

Eustomin<smiles>COc1cc(O)c2c(=O)c3c(O)c(OC)c(OC)c(OC)c3oc2c1</smiles>

Demethyleustomin<smiles>COc1cc(O)c2c(=O)c3c(OC)c(OC)ccc3oc2c1</smiles>

Decussatin<smiles>COc1cc(O)c2c(=O)c3c(O)ccc(OC)c3oc2c1</smiles>

Methylbellidifolin

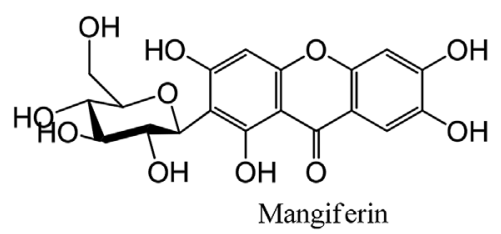

a

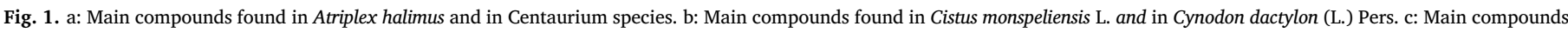
found in Glaucium flavum Crantz., Juncus acutus L. and in Typha spp.

succulent nature of leaves, as well as to high photosynthetic capacity and high content in photosynthetic pigments (Bendaly et al., 2016). However, according to the latter study (Bendaly et al., 2016), the decreased plant growth under high salinity levels may be due to high energy consumption for the biosynthesis of proline, glycinebetaine and sucrose for osmoregulatory purposes, while Panta et al. (2014) noted 
Cistus monspeliensis L.<smiles>C=CCc1ccc(O)c(OC)c1</smiles>

Carvacrol Eugenol

Cynodon dactylon (L.) Pers.<smiles>Oc1ccc([C@@H]2c3cc(O)cc(O)c3[C@@H](c3ccc(O)cc3)[C@@H]2c2cc(O)cc(O)c2)cc1</smiles>

Leachianol $\mathrm{F}$<smiles>CC(C)(C)Oc1ccc(C(=O)[C@@H]2c3cc(O)cc(O)c3[C@@H](c3ccc(O)cc3)[C@H]2c2cc(O)cc(O)c2)cc1</smiles>

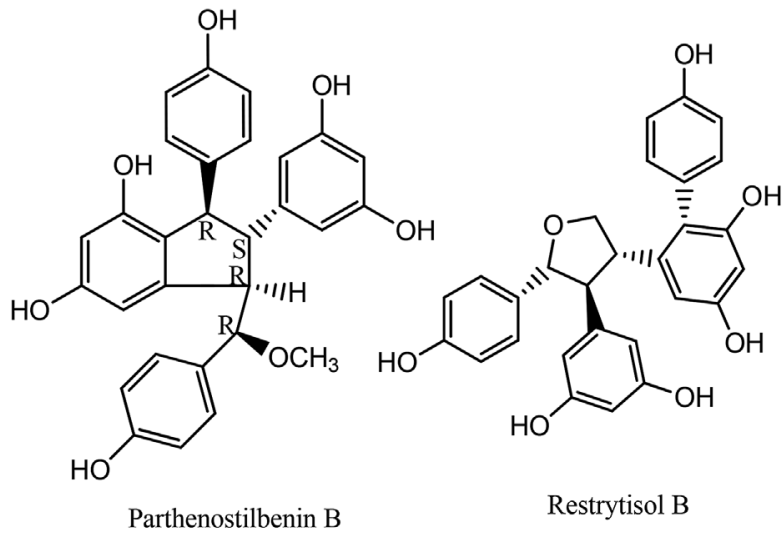<smiles>Oc1ccc([C@H]2c3c(O)cc(O)cc3[C@@H](c3ccc(O)cc3)[C@H]2c2cc(O)cc(O)c2)cc1</smiles>

Pallidol<smiles>OC1=CC2C(C=C1)C=C1C3C(O)=CC(O)=C(C13)[C@H](c1ccc(O)cc1)[C@H]2c1ccc(O)cc1</smiles>

Laetevirenol A<smiles>CCO[C@H](c1ccc(O)cc1)[C@@]1(C)c2cc(O)cc(O)c2[C@@H](c2ccc(O)cc2)[C@H]1c1cc(O)cc(O)c1</smiles><smiles>Oc1ccc(/C=C2\c3cc(O)cc(O)c3[C@@H](c3ccc(O)cc3)[C@H]2c2cc(O)cc(O)c2)cc1</smiles>

b

Fig. 1. (continued)

that annual biomass production amounts to 14 ton ha ${ }^{-1}$ in plants irrigated with saline water $\left(20 \mathrm{dS} \mathrm{m}^{-1}\right)$.

\subsubsection{Chemical composition}

Mediterranean saltbush (Atriplex halimus L.) shows a very interesting and varied chemical composition; it is a rich source of phenolic compounds, such as various flavonol glycosides, namely syringetin 3-O$\beta$-D-rutinoside, syringetin 3-O- $\beta$-D-glucopyranoside and isorhamnetin 3-
$O$ - $\beta$-D-rutinoside (narcissin) which have been isolated from a $60 \%$ methanolic fraction, as well as atriplexoside A (3'-O-methylquercetin-4'-O$\beta$ - $D$-apiofuranoside-3- $O$ - $\left(6^{\prime \prime}\right.$ - $O$ - $\alpha$ - $L$-rhamnopyranosyl- $\beta$ - $D$-glucopyranoside) which has been detected in a $20 \%$ methanolic fraction of the aerial plant parts (El-Aasr et al., 2016) (Fig. 1a). Another two important phenolic compounds, namely two flavonol glycosides, designated as atriplexoside A [3'-O-methylquercetin-4'-O- $\beta$-apiofuranoside-3-O-(6"$O$ - $\alpha$-rhamnopyranosyl- $\beta$ glucospyranoside) $]$ and atriplexoside B [3'-O- 


\section{Glaucium flavum Crantz.}<smiles>COc1cc2c(cc1OC)-c1c(OC)c(OC)cc3c1C(C2)N(C)CC3</smiles>

\section{Juncus acutus L.}<smiles>C=Cc1cc2c(cc1C)-c1ccc(O)c(C)c1CC2</smiles>

Juncunol<smiles>O=C1OC(Cc2ccccc2)c2cccc(O)c21</smiles>

Typhaphthalide

Typha spp.<smiles>O=C1OC(/C=C/c2ccccc2)Cc2cccc(O)c21</smiles>

Typharin

c

Fig. 1. (continued)

methylquercetin-4'-O-(5"-O- $\beta$-xylopyranosyl- $\beta$-apiofuranoside)-3-O(6"-O- $\alpha$-rhamnopyranosyl- $\beta$-glucopyranoside)] were also identified by Kabbash and Shoeib (2012), as also two phenolic glycosides, one ecdysteroid, one megastigmane and two methoxylated flavonoid glycosides. Tannin, alkaloid, saponin, lignin and fiber contents were relatively low, while proteins were detected in moderately high levels and were associated with high digestibility (Benhammou et al., 2009; Bouazza et al., 2012). Also interesting to point out is that the concentrations of bioactive constituents vary within the growing season, reaching high protein and low fiber levels during February to April and low protein and high fiber levels during August and October (ElShatnawi and Mohawesh, 2000).

\subsubsection{Health effects}

Atriplex halimus exhibits interesting antioxidant effects, mainly by acting as a free radicals scavenger, while it has been reported to being able to reduce elevated blood glucose and hepatic levels in streptozotocin-induced diabetic rats (El-Aasr et al., 2016; Kabbash and Shoeib, 2012). Anti-leishmanial and anti-multidrug resistance activity were also observed, with these effects being directly attributed to its high content in phenolic compounds (Kabbash and Shoeib, 2012). The cytotoxic activity of the species has been also reported by El-Aasr et al. (2016) who observed a high selectivity against breast (MCF-7) and prostate (PC3) carcinoma cells. Interestingly, in a deepen study carried out by El-Aasr et al. (2016) the antimicrobial activity of the isolated compounds from A. halimus was assessed, where a broad spectrum of antibacterial activity against both Gram-negative (E. coli and Acinetobacter baumanii) and Gram-positive (S. aureus, Streptococcus pyogenes and Enterococcus feacalis), and even antifungal activity against Candida species was detected. The immunomodulatory effect of phenolic compounds was also carried out, and a pronounced reduction of the induced IL-6, IL-1 $\beta$, TNF- $\alpha$ and COX-2 to normal levels was observed in LPSinflammation models, which suggests their role as immunomodulators (El-Aasr et al., 2016). Other health effects of the species include the use of decoctions against rheumatism, heart diseases, diabetes (Pieroni, 2017; Walker et al., 2014).

No signs of toxicity have been reported for Atriplex halimus L. so far. However, considering that the species is a heavy metal hyperaccumulator, there should be great concerns regarding human toxicity from consumption of wild plants gathered in degraded soils due to heavy metal pollution (Mateos-Naranjo et al., 2013; Pérez-Esteban et al., 2013). 


\subsection{Cakile maritima Scop.}

\subsubsection{Botanical aspects}

European searocket (Cakile maritima Scop., Brassicaceae) is a facultative halophyte distributed along the Mediterranean seashores (Megdiche et al., 2009). According to Megdiche et al. (2009) the salt tolerance of this species is based on the expression of a cystatin gene which is involved in plant development and defense against abiotic constraints, while Amor et al. (2006) reported that salt tolerance is associated with high antioxidative enzymes activities and the capacity to limit oxidative damage through increased antioxidant compounds content. One of the suggested protection mechanisms of C. maritima against salt stress is the increased endogenous level of compatible osmolytes such as proline which protect membrane stability (Megdiche et al., 2009), as well as the increased leaf thickness and succulence (Debez et al., 2006).

\subsubsection{Chemical composition}

Cakile genus contains 16 distinct glucosinolates which mainly consist of isopropylglucosinolate, allylglucosinolate and s-butylglucosinolate (Davy et al., 2006), while Iranshahi (2012) reported various isothiocyanates or mustard oils. Radwan et al. (2008) identified $\beta$ sitosterol and oleic and linoleic fatty acid methyl esters in the aerial part extracts, while the isolated four new glucosinolates for the species, namely glucotropaelin, 2- methyl butyle glucosinolates, ethyl glucosinolate and 4- pentyl glucosinolates. Moreover, C. maritima is very rich in phenolic choline esters, while flowering shoots contain flavonol glucosides and shoots phenolic compounds consist of benzoic and cinnamic phenolic acids (Davy et al., 2006). Seeds of $C$. maritima contain high amounts of oil ( $42 \%$ on a d.w. basis) which consist mostly of triacylglycerols, while the most abundant fatty acid was erucic acid ( $>25 \%$ ) which makes it unsuitable for human or animal consumption due to negative effects on cardiac muscles (Zarrouk et al., 2003). However, other uses of seed oil have been proposed such as the production of erucamide for industrial purposes, considering the high oil content of seeds, as well as for pharmaceutical purposes (Zarrouk et al., 2003). The leaves extracts of the species are also a valuable source of antioxidant compounds, while its potency depends on plant part and growth stage, as well as on environmental conditions (Ksouri et al., 2008).

\subsubsection{Health effects}

Sea rocket is attributed with diuretic, digestive, antiscorbutic and purgative properties, as well as with activities against jaundice, lympatic and nervous system disorders and lung viscid phlegm and scrofulous infections (Davy et al., 2006; Ksouri et al., 2012). Moreover, Meot-Duros et al. (2008) reported a strong antioxidant activity and inhibitory effects against Pseudomonas marginalis, $P$. aeruginosa and Candida albicans, while Radwan et al. (2008) noted significant molluscicidal activity.

No toxicity effects have been reported for Cakile maritime so far.

\subsection{Centaurium erythrea L., C. maritimum Rafn.}

\subsubsection{Botanical aspects}

Sea centaury (Centaurium maritimum (L.) Fritsch) and common centaury (C. erythrea Rafn) are widely distributed in the Mediterranean region, while they can also be found in saline soils (Mišić et al., 2009; Šiler et al., 2014). According to Mišić et al. (2012) C. maritimum responds to salinity and water deficit through osmoregulatory mechanisms by synthesizing trehalose and polyols which are the main components of plant defense against salt stress.

\subsubsection{Chemical composition}

Centaurium species contain a wide variety of bioactive compounds, among them secoiridoid glycosides (gentiopicrin, swertiamarin, and sweroside) and xanthones (eustomin, demethyleustomin, decussatin, methylbellidifolin, and mangiferin) (Šiler et al., 2014) (Fig. 1a). Furthermore, Mišić et al. (2013) reported that hairy roots of $C$. maritimum produces secoiridoid glycosides that are natural compounds with great importance for the food and pharmaceutical industry. Phenolic compounds such as esters of hydroxycinnamic acids, namely p-coumaric, ferulic, and sinapic acids were also identified in C. erythraea extracts (Valentāo et al., 2002).

\subsubsection{Health effects}

Regarding their medicinal properties, Centaurium species exhibit antidiabetic, digestive, antipyretic, spasmolytic, antiflatulent, and antioxidant activities, as well as beneficial effects against cardiovascular, kidney, muscular and muscular-sceletical disorders (Đorđević et al., 2017; González-Tejero et al., 2008; Pieroni et al., 2004; Šiler et al., 2014). Other therapeutic properties include the use of leaves decoctions and ingestions against constipation, obesity, arthritis and dismenorrhya (Hanlidou et al., 2004), while Polat and Satil (2012) has been also reported the use of leaf infusions in oil or honey against stomach ache, ulcers, enteritis and waist pain. Antioxidant properties are also evidenced by $C$. erythraea plants, namely acting as superoxide radical scavenger or as inhibitor of xanthine oxidase (Valentāo et al., 2002). It is also interesting to highlight that $C$. erythrea has been used in traditional medicine for treatment of diabetes, since according to Hamza et al. (2011) a significant decrease in fasting blood glucose levels in mice was detected comparing to control group; total cholesterol and serum insulin concentrations also decreased in a significant manner. Besides, the extracts of aerial parts and roots of several centaury species (Centaurium erythraea, C. tenuiflorum, C. littorale ssp. uliginosum, and C. pulchellum) exhibited considerable antibacterial and high antifungal activity suggesting their use in food industry as additives for food safety and preservation (Šiler et al., 2014). In addition, oral administration of $10 \mathrm{ml} \mathrm{kg}^{-1}$ of aqueous extracts of $C$. erythraea exhibited a diuretic effect on rats (Haloui et al., 2000).

No toxicity effects have been reported for Centaurium species so far. However, according to Tahraoui et al. (2010) oral administration of aqueous extracts of $C$. erythraea in mice at doses of $0-15 \mathrm{~g} \mathrm{~kg}^{-1} \mathrm{BW}$ or administration via the intraperitoneal route at doses of $0-14 \mathrm{~g} \mathrm{~kg}^{-1} \mathrm{BW}$ showed no acute or sub-chronic toxicity. In addition, a commercial pharmaceutical product that contains extracts of $C$. erythrae and is usually administered against dyspepsia showed no toxicity effects and has been called as safe for human consumption (Tagliati et al., 2008). Another plant mixture extract (P-9801091) which is used against hyperglycemia and contains extracts of $C$. umbellatum showed no biochemical and histological changes comparing to control treatment when administered in mice at a dose of $20 \mathrm{mg} \mathrm{kg}^{-1}$ (Petlevski et al., 2008).

\subsection{Cistus monspeliensis $L$.}

\subsubsection{Botanical aspects}

Montpellier cistus (Cistus monspeliensis L.) is a salt tolerant species of the Cistaceae family (Li Rosi et al., 2010; Torrecillas et al., 2003). According to Torrecillas et al. (2003) the osmotic adjustment through the inclusion of $\mathrm{Na}$ and $\mathrm{Cl}$ and the reduction of the canopy area for regulation of water losses are the main salt tolerance mechanisms of the species. The resin (ladano), produced by the glandular trichomes of Cistus species contains a wide variety of compounds (Papaefthimiou et al., 2014), while the essential oils of several Cistus species can be used in the food industry as additives (Loizzo et al., 2013).

\subsubsection{Chemical composition}

Monpellier cistus contains a wide variety of compounds, among them terpenes: limonene, p-cymene, 1,8-cineole, linalyl acetate, viridiflorol, manoyloxide, 13-epi-manoyl oxide, neophytadeine, terpineol4, $\alpha$-terpineol, safranal, cyclosativene, $\beta$-caryophyllene, $\alpha$ - and $\beta$ - 
cadinol; fatty acids and their derivatives: (Z,Z,Z)-9,12-15-octadecatrienoic acid, (Z,Z)-9,12-octadecadienoic acid, tetradecanoic acid, eicosanoic acid, docosanoic acid, tetracosanoic acid, hexacosanoic acid; and phenolic compounds: carvacrol, eugenol, methylisoeugenol (Jemia et al., 2013; Loizzo et al., 2013; Papaefthimiou et al., 2014) (Fig. 1b). According to Nicoletti et al. (2015), Cistus sp. shows strong in vitro antioxidant activity due to its high content in phenolics, flavonoids and tannins, while they suggested a discrimination between the various species of the genus depending on the presence of diterpenes which are usually detected in C. mospeliensis and C. libanotis. Barrajón-Catalán et al. (2011) also isolated from the aerial parts of plants the flavonoid apigenin diglucoside and four phenolic acids derivatives (uralenneoside, gentisoyl glucoside, 3,4'-dihydroxypropiofenone-3- $\beta$-D-glucoside, hydroxyl-ferulic acid hexoside). The labdane diterpene $(+)-19$-acetoxycis-clerodan-3-en-15-oic acid was also identified in C. monspeliensis leaves, while among hydrocarbons isolated from leaves of C. monspeliensis collected from Tunisia, were pentacosane, heptacosane, octacosane, nonacosane, and hentriacontane (Jemia et al., 2013). Diurnal and seasonal variation in composition of essential oil from the leaves of C. monspeliensis have also been reported (Angelopoulou et al., 2002).

\subsubsection{Health effects}

Several species of the Cistaceae family are reported to have medicinal properties and are used as ingredients in traditional medicine formulations (Bedoya et al., 2009; Sayah et al., 2017). In a previous study, Attaguile et al. (2000) reported that extracts from aerial parts of C. monspeliensis exhibit antioxidant capacity and protective activities against DNA cleavage. Similarly, Shimoda et al. (2012) reported that leaf extracts display antioxidant activity and promote the energy metabolism pathways in human intestinal cells, while Sayah et al. (2017) reported in vivo and in vitro anti-inflammatory and analgesic capacity, as well as activities against key enzymes associated with hyperglycemia, for aerial plant parts extracts in animal studies. The extracts from leaves and flowers of C. monspeliensis also exhibited considerable antibacterial activity against Gram-positive bacteria such as Staphylococcus aureus and S. epidermidis (Papaefthimiou et al., 2014; Sassi et al., 2017). Finally, and not least important to point out is the in vitro antiproliferative and cytotoxic activity of the species against the human epithelial prostate cells and human melanoma cell line A-375 (Jemia et al., 2013; Vitali et al., 2011), as well as the activity of leaves essential oils against neurogenerative disorders (Loizzo et al., 2013).

No toxicity effects have been reported for Cistus monspeliensis so far.

\subsection{Cynodon dactylon (L.) Pers.}

\subsubsection{Botanical aspects}

Bermudagrass or Scotch grass (Cynodon dactylon (L.) Pers.) is a perennial omnipresent and difficult to control weed which is reproduced vegetatively with stolones and rhizomes (Horowitz, 1996). The aerial parts of the plant are good cattle forage, however they are also used for medicinal purposes as well as in landscaping (Pessarakli, 2015). The salt tolerance of this species is based on its ability to accumulate proline for osmoregulatory purposes, while some ecotypes of C. dactylon exhibited lower uptake rates of $\mathrm{Na}^{+}$and $\mathrm{Cl}^{-}$and increased uptake of $\mathrm{Ca}^{2+}$ and $\mathrm{K}^{+}$(Hameed and Ashraf, 2008).

\subsubsection{Chemical composition}

Bermudagrass contains a wide variety of chemical constituents such as eachianol G, leachianol F, parthenostilbenin B, parthenostilbenin A, restrytisol B, caraphenol C, pallidol, laetevirenol A, quadrangularin $\mathrm{B}$, quadrangularin $\mathrm{C}$, quadrangularin $\mathrm{A}$, and parthenocissine $\mathrm{A}$ ( $\mathrm{Li}$ et al., 2017) (Fig. 1b). According to (Muthukrishnan et al., 2015), ethyl acetate extracts of leaves contain several flavonoids (catechin, rutin, quercetin, kaempferol and myricetin), carotenoids (violaxanthin, lutein, zeaxanthin and $\beta$-carotene) and chlorophyll-b, while Biswas et al. (2017) detected significant amounts of ascorbic acid, caffeic acid and syringic acid. Other detected compounds in ethanolic extracts of leaves include glycerin, 9,12-Octadecadienoyl chloride, (Z,Z), hexadecanoic acid, ethyl ester, ethyl $\alpha$-d-glucopyranoside, linoleic acid and phytol (Jananie et al., 2011).

\subsubsection{Health effects}

Bermudagrass presents very interesting medicinal properties. The extracts and decoctions of rhizomes from this species exhibit several anti-inflammatory, diuretic and antiemetic activities (Rai et al., 2010; Tuttolomondo et al., 2014). Besides to these effects, Singh et al. (2007) reported that the aqueous extracts of the species possess high antidiabetic activity, while (Soraya et al., 2015) found that the extracts from rhizomes possess angiogenic activity due to their increasing effects on the expression of VEGF (vascular endothelial growth factor). The wound healing activity in animal models was also reported by (Biswas et al., 2017), who attributed the effect of aqueous extracts ointments to its content in phenolic acids and flavonoids which exhibits anti-oxidative activity and help in collagenesis. Furthermore, ethanolic extracts of the whole plant exerted moderated antibacterial activity against Gram positive and Gram negative bacteria, while chloroform extracts had a pronounced antibacterial effect against Staphylococcus aureus (Marasini et al., 2015). Ethnopharmacological studies have also confirmed the use of Bermudagrass as digestive and against kidney disorders (GonzálezTejero et al., 2008), while Neves et al. (2009) and Passalacqua et al. (2007) reported various medicinal effects for dry roots and aerial parts, including detoxifying, gastroprotective, anti-inflammatory, mild laxative, antirheumatic and diuretic properties.

Regarding toxicity effects of C. dactylon, Yadav and Nath (2017) reported that the administration of plant extracts at doses of $200-800 \mathrm{mg} \mathrm{kg}^{-1}$ in mice showed no acute toxicity effects.

\subsection{Frankenia laevis $L$.}

\subsubsection{Botanical aspects}

Sea health (Frankenia laevis L.) is a halophyte species that can be found in coastal areas of Southern Europe (Lopes et al., 2016). It is a scabrid puberulent shrub with a height of 0.1-0.3 m (Hussein, 2004a). The species which belongs to Frankeniaceae family exhibited a significant salt and gypsum tolerance, with sunken salt glands on their leaves (Manning and Helme, 2014).

\subsubsection{Chemical composition}

Sea health have a pronounced content of phenolic compounds, being chlorogenic acid and catechin the major compounds (Jdey et al., 2017). Phenolic anionic conjugates were also isolated and identified as gallic acid-3-methylether-5-sodium sulphate, acetophenone-4-methyl ether-2-sodium sulphate, ellagic acid-3,3'-dimethylether-4,4'-di-sodium sulphate and ellagic acid-3-methyl ether-4-sodium sulphate (Hussein, 2004a). In the study of Hussein (2004b) two new flavonol di-sodium sulphates and an ellagic acid methyl ether mono-sodium sulphate were also characterized and identified as 3,7-di-sodium sulphate of kaempferol, 3,7-di-sodium sulphates of quercetin and $4^{\prime}$-mono-sodium sulphate of ellagic acid-3-methylether. Apart from this class of chemical compounds, a pronounced content of volatile compounds is also present, namely hexadecanoic acid, the major compound identified in $F$. laevis, followed by methyl linoleate, $(E, E)$-farnesyl acetate, $(E)$-nerolidol and benzyl benzoate. In smaller amounts, are also present dodecanoic acid, benzyl benzoate, methyl hexadecanoate, benzyl cinnamate, tricosane, pentacosane, hexacosane, heptacosane, octacosane, nonacosane and 1-docosene (Mahjoub et al., 2010). Therefore, fatty acids and their esters, hydrocarbons and their derivatives (alkanes, alkenes, alcohols and aldehydes), terpenoids (oxygenated monoterpenes, sesquiterpene hydrocarbons and oxygenated sesquiterpenes) and aromatic compounds are the main classes present on sea health essential oil composition (Mahjoub et al., 2010). However, the quantitative composition and the relative proportions of oil components are widely 
influenced by the genotype, ontogenic development and even environmental and growing conditions.

\subsubsection{Health effects}

Frankenia laevis is a halophyte that has been widely recognized for its prominent antimicrobial effects, namely as antibacterial against both Gram-positive (S. aureus, S. epidermidis and Micrococcus luteus) and Gram-negative (E. coli and Salmonella typhimurium) bacteria (Saïdana et al., 2010). Interestingly to highlight is that this significant potential is reached by using both the aerial plant parts extract and essential oils (Jdey et al., 2017; Mahjoub et al., 2010). Nevertheless, at the tested concentrations, no positive antifungal effects were noted against different fungi species, namely Fusarium oxysporum, Aspergillus niger, Alternaria spp. and Penicillium spp. These results may be explained by the different levels of complexity existent between bacteria and fungi. On the other hand, pronounced antioxidant effects were also noted for $F$. laevis, mainly acting as a free radical's scavenger, reducing power agent and lipid peroxidation inhibitor (Jdey et al., 2017). In the same line, the same authors reported a high potential of diphenolase activity inhibition. This data suggests an upcoming and effective use of this plant as a new natural skin-whitening agents.

No toxicity effects have been reported for F. laevis so far.

\subsection{Glaucium flavum Crantz.}

\subsubsection{Botanical aspects}

Yellow hornpoppy (Glaucium flavum Crantz., Papaveraceae) is a common herb of the Mediterranean region, usually found at areas with a wide range of soil salinity levels (Arafa et al., 2016; Cambrollé et al., 2011). The species has the ability to tolerate up to $300 \mathrm{mM} \mathrm{NaCl}$ salinity levels, mostly due to plant's ability to maintain a particularly low assimilation of $\mathrm{CO}_{2}$ and the little effects of salinity on photosystem PSII (Cambrollé et al., 2011).

\subsubsection{Chemical composition}

Studies on chemical composition of G. flavium have identified several isoquinoline alkaloids of the aporphine class such as glaucine, pontevedrine, oxoglaucine, and catalane which were isolated from the aerial plant parts (Arafa et al., 2016). In an earlier study of Daskalova et al. (1988), ethanolic extracts of aerial parts at full blossom, revealed the presence of some minor alkaloids, namely dihydropontevedrine, dihydrosanguinarine, dihydrochelerythrine and dihydrochelirubine, while Petitto et al. (2010) identified apart from glaucine, talikmidine, isocorydine and norisocorydine (Fig. 1c). Moreover, Bournine et al. (2013) studied the chemical composition of roots and isolated two new alkaloids, namely protopine and bocconoline. Two more alkaloids were also isolated and identified in aerial parts as N,N-dimethyl-hernovine and sanguinarine (Och et al., 2017). However, according to Doncheva et al. (2016) alkaloid profile of the species is highly depended on genotype, with three chemotypes being suggested in terms of aporphines, protopines and morpinanes content. Seeds are rich in oils (33.64\%) which consist of linoleic, oleic, palmitic and stearic acid (Ozcan, 2014).

\subsubsection{Health effects}

Glaucium flavum is considered a rich source of alkaloids which although they are associated with toxic effects, they also show strong pharmacological activity, especially as anticancer agents (Och et al., 2017). For example, Lidder et al. (2008) have reported that the combined use of diphenylprolinol and glaucine may result in cardiovascular toxicity. Moreover, Arafa et al. (2016) reported that ethanol extracts from the aerial parts of the plant possessed analgesic, antibacterial, anti-inflammatory, antifungal and cytotoxic activities. Similarly, Hadjiakhoondi et al. (2013) observed that the aerial parts alkaloid extracts exhibited cytotoxic effects against colon adenocarcinoma cell lines (HT-29, Caco-2), while Bournine et al. (2013) reported that the root methanolic extracts displayed anticancer effects against breast cancer cells. Other health effects include depressive effects of various plant parts extracts on the central nervous system (CNS) and blood glucose levels (Cabo et al., 1988, 1987), while the main bioactive compound of the species (glaucine) has been associated with various pharmacological properties, such as antitussive, antiparkinsonic, hypotensive, antiviral, cardiovascular and cytotoxic effects (Orallo et al., 1995; Spasova et al., 2008).

Considering that the species belongs to Papaveraceae family which includes plants with high amounts of alkaloids, any toxic effects of $G$. flavum could be associated with ingestion of excessive amounts of alkaloids and their side effects. Therefore, it is considered as a poisonus plant and is registered as such in FDA (Cooper and Johnson, 1998).

\subsection{Juncus acutus $L$.}

\subsubsection{Botanical aspects}

Spiny rush (Juncus acutus L. Juncaceae) is a salt tolerant species found at coastal marshes in the Mediterranean basin (Batriu et al., 2015; Fountoulakis et al., 2017). The salt tolerance of the species is associated with proline and $\mathrm{Ca}^{2+}$ and $\mathrm{Mg}^{2+}$ accumulation which contribute to plant defense mechanisms against salinity stress through osmoregulation (Boscaiu et al., 2011; Hassan et al., 2017b). Hassan et al. (2017a) observed an increase of total phenolic compounds and flavonoids in the aerial parts of the species under high salinity levels ( $400 \mathrm{mM} \mathrm{NaCl}$ ), whereas photosynthetic pigments were sensitive to salt-induced oxidative stress and decreased at levels higher than $100 \mathrm{mM} \mathrm{NaCl}$.

\subsubsection{Chemical composition}

The wetland plants of Juncus genus such as $J$. acutus, are considered rich sources of nitrogen-free alkylated phenanthrenoids, while they also contain secondary metabolites of various classes, such as coumarins, sterols, terpenes, stelbenes, carotenoids and so forth (Behery et al., 2013; El-Shamy et al., 2015). In the study of Behery et al. (2013) several compounds with antioxidant activity were isolated from $J$. acutus rhizomes, namely 8,8'-bidehydrojuncusol, juncunol, 5,7-dihydroxychromone and flavone derivatives (apigenin, luteolin, chrysoeriol, luteolin-7-O- $\beta$-glucoside and hydnocarpin (Fig. 1c). Plant culms are rich in soluble carbohydrates (myo-inositol, clicerol, sorbitol, fructose, glucose and sucrose) which are used in salt tolerance mechanisms (Gil et al., 2011).

\subsubsection{Health effects}

Juncus acutus constituents, especially nitrogen-free alkylated phenanthrenoids, exert a pronounced antioxidant activity and biological activities, including anti-inflammatory, cytotoxicity, anti-leukaemic, anti-algal and cognitive-enhancing properties (Behery et al., 2013; Rodrigues et al., 2017). Moreover, Rodrigues et al. (2014) reported significant in vitro cytotoxicity of juncunol against HepG2, MDA-MB468 and HeLa human cancer cells, which is probably associated with radical scavenging activity of the species. Ethanolic extracts of the aerial parts of the plants showed significant anti-eczematic activity in animal studies, with compounds markhamioside $\mathrm{F}$ and as canthoside $\mathrm{B}$ having the highest potency (Awwad, 2006).

No toxicity effects have been reorted for $J$. acutus so far.

\subsection{Limonium sinuatum (L.) Mill.}

\subsubsection{Botanical aspects}

Sea lavender or statice (Limonium sinuatum (L.) Mill.) is a salt tolerant flower crop and member of the Plumbaginaceae family (Grieve et al., 2005; Rivoal and Hanson, 1994). Limonium species belongs to recretohalophytes and they have the ability to secrete salts from their leaves as a means to tolerate salinity stress (Hassan et al., 2017b). Moreover, according to Rivoal and Hanson (1994) Limonium plants tend 
to accumulate choline-O-sulphate under saline conditions for osmoregulatory purposes, while Raman and Rathinasabapathi (2003) associated salinity tolerance with $\beta$-alanine betaine accumulation which serves as an osmoprotectant and is usually detected in plants of Plumbaginaceae family.

\subsubsection{Chemical composition}

The flowers of Limonium sinuatum contain gallic acid, ferulic acid, quercetin, rutin and epigallocatechin (Xu et al., 2017). One phenolic acid; homogentisic acid and two flavonoids; catechin and epicatechin were also isolated in flower extracts of the species (Li et al., 2014), while Ross (1984) identified myricetin-3'- methyl ether-7-O-B-D-glucopyranoside and isorhamnetin-7-0-B-D-glucopyranoside.

\subsubsection{Health effects}

Although no reports regarding the health effects of the species are available, its potential health effects could be associated with the antioxidant potential of flower extracts (Li et al., 2014; Xu et al., 2017). Moreover, according to Xu et al. (2017), flower decoctions have been used for their anti-aging properties. However, Wiszniewska et al. (2011) have reported a case of occupational asthma and rhinitis induced by pollen grains and leaves of $L$. sinuatum.

No toxicity effects have been reorted for $L$. sinuatum so far.

\subsection{Phragmites australis (Cav.) Trin. ex Steud.}

\subsubsection{Botanical aspects}

Common reed or reed (Phragmites australis (Cav.) Trin. ex Steud.; synonym. Phragmites communis Trin.) is a perennial weed which develops an extensive root system (Mal and Narine, 2004). This species is considered as a salt tolerant species through the adjustment of osmotically active solutes levels in leaves (Lissner and Schierup, 1997). Plant parts such as culm and rhizomes have been traditionally used for human consumption, while raw leaves can reduce horse stomach flatulence (Menale and Muoio, 2014).

\subsubsection{Chemical composition}

Common reed presents a varied chemical composition. The compounds aurantiamide acetate, 2,3-dihydroxy-1-(4-hydroxy-3,5-dimethoxyphenyl)-1-propanone, ferulic acid, p-coumaric acid, syringic acid, vanillic acid, p-hydroxy benzoic acid, p-hydroxybenzaldenhyde, palmitic acid, heptadecanoic acid, $\beta$-sitosterol, stigmasterol, $\alpha$-D-glucose and $\beta$-D-glucose were isolated and identified from the rhizomes of this species (Gao et al., 2009). Moreover, Choi et al. (2009) identified methyl gallate, (+)-lyoniresinol, and (+ )-lyoniresinol-3 $\alpha$-O- $\beta$-D-glucopyranoside from reed rhizomes.

\subsubsection{Health effects}

Regarding the medicinal properties of common reed, Kiviat and Hamilton (2001) reported that this species is used in traditional medicine for the treatment of various diseases, while Chen et al. (2013) found that aqueous extracts from the rhizomes of $P$. australis exhibited antioxidant and hepatoprotective activities. Furthermore, it is important to point out that extracts from leaves possess anti-melanogenesis and antioxidant activities (Sim et al., 2017), while González-Tejero et al. (2008) referred to its traditional uses against nutritional disorders. Moreover, Zhu et al. (2017) reported in vitro inhibition of inflammatory mediators and pro-inflammatory cytokines, as well antiviral effects of water soluble crude extracts, while (Borer et al., 2012) noted significant in vivo beneficial effects on lipid metabolism and erythrocyte antioxidant defense system in rats. Other therapeutic effects reported in ethnopharmacological studies include its uses in folk medicine against sore throat (Palombo and Semple, 2001), while Viegi et al. (2003) described its uses in folk veterinary medicine.

No toxicity effects have been reorted for $P$. australis so far.

\subsection{Tamarix gallica $L$.}

\subsubsection{Botanical aspects}

French tamarisk (Tamarix gallica L., Tamaricaceae) is a deciduous, herbaceous shrub or tree, which naturally grows in arid and semiarid areas of the Mediterranean basin (Molina et al., 2012; Terrones et al., 2016). It has been used in traditional medicine for many centuries, while it is also commonly used as an ornamental plant or as a fuel wood (Ksouri et al., 2012; Panta et al., 2014). According to Borer et al. (2012) apart from salt tolerant, the species also exhibits tolerance in high calcium environments through foliar partitioning and secretion mechanisms.

\subsubsection{Chemical composition}

French tamarisk contains a wide variety of chemical constituents, among them phenolic acids (gallic, synnapic, chlorogenic, syringic, vanillic, $p$-coumaric, and trans-cinnamic acids), flavonoids (catechin, (-)-epicatechin, quercetin, quercetin-3-O-glucuronide, isoquercetin, apigenin, kaempferol, kaempferol-3-O- $\beta-D$-glucuronide, rhamnocitrin, amentoflavone, flavone, resveratrol-3-O-glucoside), coumarins and tannins (Boulaaba et al., 2015; Jdey et al., 2017; Ksouri et al., 2009), with significant differences in their relative contents according to plant parts used, harvesting stage and growing and extraction conditions (Ksouri et al., 2008). According to the latter study, polyphenols content was higher in flowers than leaves, hence the higher antioxidant potency of leaves, while significant differences were observed between different ecotypes of the species. Stem bark contains coniferyl alcohol 4-sulphate and other phenolic and flavonoid sulphates, such as kaempferol 4'methyl ether 3-sulphate, and tamarixetin 3-sulphate were also identified (Tomas-Barberán et al., 1990). Other reported flavonoids include 3,5,3'-trihydroxy-7,4'-dimethoxyflavone, 3,5,7-trihydroxy-4'-methoxyflavone and 5-hydroxy-3,7,4'-trimethoxyflavon, O-Methylated and glucuronosylated flavonoids, as well as rhamnetin, tamarixetin, rhamnazin, KGlcA, KGlcA-Me, QGlcA, and QGlcA-Me (Hmidene et al., 2017; Lefahal et al., 2017). Also, pronounced levels of carnosol, capsaicin, 6shogaol, 6-gingerol and their corresponding derivatives, and even vitamins, terpenoids (carotenoids and essential oils) have been identified (Boulaaba et al., 2013; Ksouri et al., 2009), which makes this plant a potential source of bioactive compounds for multiple applications.

\subsubsection{Health effects}

Tamarix gallica exhibits prominent free radical's scavenging, reducing power and lipid peroxidation inhibition effects (Jdey et al., 2017; Ksouri et al., 2009). Besides, the effectiveness varied depending from the plant part used, i.e. flowers exhibited a higher biological activity as compared to the leaves (Ksouri et al., 2009). Appreciable antimicrobial effects were also stated, namely antibacterial and antifungal properties against human pathogen strains, while silver nanoparticles synthesized with Tamarix gallica extract exhibited significant antibacterial activity against Escherichia coli (Ksouri et al., 2009; López-Miranda et al., 2016). Jdey et al. (2017) observed a prominent in vitro antibacterial activity of this halophyte against the pathogenic bacteria, $S$. aureus and S. enterica strains, while Ksouri et al. (2009) found an appreciable effect against Staphylococcus epidermidis, Micrococcus luteus, E. coli and P. aeruginosa strains. A weak to moderate antifungal activity was also noted against the Candida species: Candida albicans, C. glabrata, C. kefyr, C. holmii and C. sake strains (Boulaaba et al., 2013; Ksouri et al., 2009). On the other hand, and taking into account that oxidative stress is among the factors causing cancer-related deaths, the abundance in bioactive molecules with antioxidant capacity of $T$. gallica, motivated the investigation of the anticancer potential of the species. Boulaaba et al. (2015) stated that is halophyte not only prevents cancer formation but also the proliferation of cancer cells. The authors found that T. gallica extract significantly inhibited Caco-2 cell growth as also decreased DNA synthesis, which confirm their effect on Caco- 2 cell proliferation, as also arrested cell mitosis at G2/M phase (Boulaaba et al., 2013). Taken these facts 
together and considering the changes occurred in the cell-cycle-associated proteins (cyclin B1, p38, Erk1/2, Chk1 and Chk2), the authors proposed T. gallica as a promising source of anticancer biomolecules (Boulaaba et al., 2013). Bettaib et al. (2017) have also reported the protective effects of hydroethanolic extracts of shoots against oxidative stress of intestine epithelial cells (IEC-6), while Sehrawat and Sultana (2006) suggested significant protective effects of methanolic extracts of T. gallica aerial parts against liver carcinogenesis. Bensatal and Ouahrani (2008) have also observed inhibitory effects of aerial parts extracts against crystallization of calcium oxalate which results in stone formation in kidneys and the urinary tract. Moreover, T. gallica extracts are one of the ingredients of Liv.52, a herbal hepatoprotective medicine which has been used against alcohol induced liver diseases (de Silva et al., 2003; Huseini et al., 2005). Finally, it is also important to highlight the widespread use of $T$. gallica in traditional medicine as hepatotonic, expectorant, stimulant, as well as in the treatment of several liver disorders, an anti-inflammatory and even anti-diarrheic (Ksouri et al., 2009). Phenolic extracts of $T$. gallica also displayed antihyperlipidemic activity, since they decreased the levels of cholesterol, triglycerides, LDL-C and VLDL-C and increased the HDL-C level (Naveed et al., 2015). Other uses include its application in folk veterinary medicine (Viegi et al., 2003), cicatrizing and antiseptic effects (Ksouri et al., 2012), the use of decoctions against eye diseases, colds, tonsillitis and as a sudorific agent (Hammiche and Maiza, 2006), as well as its use in warts healing (Montesano et al., 2012).

Regarding toxicity effects, the administration of methanolic and ethyl acetate extracts of $T$. gallica at doses up to $3000 \mathrm{mg} \mathrm{kg}^{-1} \mathrm{BW}$ in rats showed no acute toxicity symptoms (Urfi et al., 2016).

\subsection{Typha spp.}

\subsubsection{Botanical aspects}

Common cattail (Typha latifolia L.,Thyphaceae) and narrowleaf cattail (Typha angustifolia L.) are perennial species commonly found in wet or saturated soils in marshes, fens and other areas in the Mediterranean basin (Grace and Harrison, 1986), while Typha latifolia shows lower salt tolerance than T. angustifolia (McMillan, 1959).

\subsubsection{Chemical composition}

Typha rhizomes present a wide variety of chemical compounds, among them saponins, coumarins and flavonoids (Fruet et al., 2012). The compounds typhaphthalide, typharin, sitosterol, afzelechin, epiafzelechin, (+)-catechin, and (-)-epicatechin were also isolated and identified from rhizomes of Typha capensis Rohrb. (Shode et al., 2002), nonacosanol and lupeol acetate were detected in dry flowers and leaves of T. angustifolia (Varghese et al., 2009) (Fig. 1c). Moreover, the cerebrosides, 1-O-(beta-d-glucopyranosyloxy)-(2S,3S,4R,8Z)-2-[(2'R)-2'-hydroxytricosanoylamino]-8-nonadecene-3,4-diol and 1-O-(beta-D-glucopyranosyloxy)-(2S,3R,4E,8Z)-2-[(2'R)-2'-hydroxynonadecanoylamino]4,13-nonadecene-3-diol, were identified in Typha angustifolia pollen grains (Tao et al., 2010). The rhizomes of T. angustifolia also accumulate considerable amounts of non-structural carbohydrates. According to Kausch et al. (1981) the rhizomes and roots which were collected at early winter contained high amounts of starch (45.03 and $22.80 \%$ in rhizomes and roots, respectively), while from late winter to spring a decrease in starch content was observed.

\subsubsection{Health effects}

Typha species are widely used as medicinal plants (Fruet et al., 2012). In a recent study, Fruet et al. (2012) reported that rhizome flour from T. angustifolia displays significant antioxidant activity. Moreover, Londonkar et al. (2013) observed that the leaves extracts exhibited strong antimicrobial activity against Salmonella typhimurium, Pseudomonas aeruginosa and Escherichia coli. Similarly, Varghese et al. (2009) reported that the extracts from dry flowers and leaves exhibited antibacterial activity against Escherichia coli and Staphylococcus aureus. In addition, silver nanoparticles synthesized using T. angustifolia leaf extract enhanced the antibiotic activity against the Gram-negative bacteria Escherichia coli and Klebsiella pneumonia (Gurunathan, 2015). Besides, extracts from aerial parts of. T. angustifolia exhibited thrombolytic and cytotoxicity activities (Umesh et al., 2014), while Qin and Sun (2005) reported that the extracts from pollen grains of T. angustifolia possessed immunosuppressive activity.

No toxicity effects have been reported for Typha species so far. Moreover, according to Grace and Harrison (1986) although T. angustifolia was suspected for cattle poisoning, no toxic effects were confirmed, while Patankar et al. (2015) evaluated acute and sub-acute toxicity and mucus membrane irritation of formulations derived from $T$. angustifolia flower extracts and reported no such effects.

\subsection{Zygophyllum album $L$.}

\subsubsection{Botanical aspects}

Zygophyllum species are salt tolerant plants native in the Mediterranean region (Hammad and Qari, 2010), while the species Zygophyllum album L. in particular has been used in traditional medicine to treat several diseases (Mnafgui et al., 2014).

\subsubsection{Chemical composition}

Ksouri et al. (2013) isolated from Z. album shoots three flavonoids; isorhamnetin-3-O-rutinoside, malvidin 3-rhamnoside and quercitin-3sulphate (flavonoids), four triterpenoid saponins; 3-O-[b-D-Glucuronic acid pyranosyl]-29-hydroxyoleanolic acid-28-O-[b-Dglucopyranosyl] ester (zygophyloside K), 3-O-[b-D-2-O-Sulphonylglucopyranosyl]-quinovic acid-28-O-[b-Dglucopyranosyl] ester (Zygophyloside G), 3-O-b-DQuinovopyranosyl-quinovic acid 28-b-D-glucopyranosyl ester, 3-O-[bD-2-O-Sulphonylquinovopyranosyl]-quinovic acid-27-O-[b-Dglucopyranosyl] ester (zygophyloside F), one phenylopropanoid; p-Hydroxyphenethyl trans-ferulate, and one sterol; b-Sitosterol-b-D-glucoside or 3-O-[b-D-glucopyranosyl]-b-sitosterol. Several volatile compounds, such as (E)- $\beta$-damascenone, delta-decalactone, 3-Nonen-2-one, safranal, Butylated hydroxytoluene, tricosane, and heneicosane were also identified in the essential oil of the aerial parts (Tigrine-Kordjani et al., 2006).

\subsubsection{Health effects}

Zyghophyllum album is also an important medicinal species. According to Mnafgui et al. (2014) the extract from leaves and flowers of Z. album exhibited antidiabetic properties through delaying carbohydrates and lipids digestion and absorption, while Ksouri et al. (2013) reported that the shoot extracts displayed appreciable antioxidant, antiinflammatory and anticancer activities. Extracts from the same species also showed a considerable antiacetylcholinesterase activity ( $\mathrm{IC}_{50}$ values $=40-58 \mu \mathrm{g} / \mathrm{mL}$ ), and thus can be suggested in pharmaceutical formulations against Alzheimer's disease (Kchaou et al., 2016). Furthermore, according to the same study (Kchaou et al., 2016), the essential oil of this plant exerts high anti-bacterial activity against Grampositive bacteria.

However, Moustafa et al. (2007) observed highly toxic effects of ethanol extracts of $Z$. album aerial parts on rats and sheep and they suggested a slight toxicity to human at high doses.

\section{Conclusions}

The Mediterranean basin is considered an important reservoir of medicinal plants and halophytes in particular. These species have been used throughout the centuries for their therapeutic properties, while there is a recent increase in global demand for herbal medicines and food supplements. Considering the great diversity in chemical composition and bioactive compounds content among the various species and the great amount of ecotypes, it is of major importance to record and describe chemical composition and health effects of these species, while 
a special focus should be given on possible toxic effects and antinutrients compounds content. Although several in vitro and in vivo animal model studies are available regarding the health effects for most of these species, there is a great lack of knowledge about their long-term effects and toxicity symptoms in clinical studies as well as the involved mechanisms of action. Therefore, although most of the studied halophytes have confirmed medicinal properties further studies are required in order to elucidate the mechanisms of action and pharmacokinetics and the involved bioactive compounds and their bioavailability in clinical studies, while official regulations about the safe consumption, recommended dose, toxicity effects and possible interactions with conventional drugs and formulations have to be established.

\section{Transparency document}

Transparency document related to this article can be found online at http://dx.doi.org/10.1016/j.fct.2018.02.031.

\section{References}

Amor, N. Ben, Jiménez, A., Megdiche, W., Lundqvist, M., Sevilla, F., Abdelly, C., 2006. Response of antioxidant systems to $\mathrm{NaCl}$ stress in the halophyte Cakile maritima. Physiol. Plant. 126, 446-457. http://dx.doi.org/10.1111/j.1399-3054.2005.00620.x.

Angelopoulou, D., Demetzos, C., Perdetzoglou, D., 2002. Diurnal and seasonal variation of the essential oil labdanes and clerodanes from Cistus monspeliensis L. leaves. Biochem. Syst. Ecol. 30, 189-203.

Arafa, A.M., Mohamed, M.E., Eldahmy, S.I., 2016. The aerial parts of yellow horn poppy (Glaucium flavum Cr.) growing in Egypt: isoquinoline alkaloids and biological activities. J. Pharmaceut. Sci. Res. 8, 323-332.

Attaguile, G., Russo, A., Campisi, A., Savoca, F., Acquaviva, R., Ragusa, N., Vanella, A. 2000. Antioxidant activity and protective effect on DNA cleavage of extracts from Cistus incanus L. and Cistus monspeliensis L. Cell Biol. Toxicol. 16, 83-90.

Awwad, A.S., 2006. Phenolic glycosides of Juncus acutus and its anti-eczematic activity. Chem. Nat. Compd. 42, 152-155.

Barrajón-Catalán, E., Fernández-arroyo, S., Roldán, C., Guillén, E., Saura, D., Seguracarretero, A., 2011. A systematic study of the polyphenolic composition of aqueous extracts deriving from several Cistus genus species: evolutionary relationship. Phytochem. Anal. 22, 303-312. http://dx.doi.org/10.1002/pca.1281.

Batriu, E., Ninot, J.M., Pino, J., 2015. Interactions between transplants of Phragmites australis and Juncus acutus in Mediterranean coastal marshes: the modulating role of environmental gradients. Aquat. Bot. 124, 29-38.

Bedoya, L.M., Bermejo, P., Abad, M.J., 2009. Anti-infectious activity in the Cistaceae family in the Iberian Peninsula. Mini Rev. Med. Chem. 9, 519-525.

Behery, F.A.A., Naeem, Z.M., Maatooq, G.T., Amer, M.A., Ahmed, A.F., 2013. A novel antioxidant phenanthrenoid dimer from Juncus acutus L. Nat. Prod. Res. 27, 155-163. http://dx.doi.org/10.1080/14786419.2012.662759.

Bendaly, A., Messedi, D., Smaoui, A., Ksouri, R., Bouchereau, A., Abdelly, C., 2016. Physiological and leaf metabolome changes in the xerohalophyte species Atriplex halimus induced by salinity. Plant Physiol. Biochem. 103, 208-218. http://dx.doi. org/10.1016/j.plaphy.2016.02.037.

Benhammou, N., Atik, F., Kadifkova, T., 2009. Antioxidant activity of methanolic extracts and some bioactive compounds of Atriplex halimus. Compt. Rendus Chim. 12, 1259-1266. http://dx.doi.org/10.1016/j.crci.2009.02.004

Bensatal, A., Ouahrani, M.R., 2008. Inhibition of crystallization of calcium oxalate by the extraction of Tamarix gallica L. Urol. Res. 36, 283-287. http://dx.doi.org/10.1007/ s00240-008-0157-1.

Berk, S., Tepe, B., Arslan, S., 2011. Screening of the antioxidant, antimicrobial and DNA damage protection potentials of the aqueous extract of Asplenium ceterach DC. Afr. J. Biotechnol. 10, 8902-8908. http://dx.doi.org/10.5897/AJB11.1011.

Bettaib, J., Talarmin, H., Droguet, M., Magné, C., Boulaaba, M., Giroux-metges, M., Ksouri, R., 2017. Tamarix gallica phenolics protect IEC-6 cells against H 2 O 2 induced stress by restricting oxidative injuries and MAPKs signaling pathways. Biomed. Pharmacother. 89, 490-498. http://dx.doi.org/10.1016/j.biopha.2017.02.047.

Biswas, K.T., Pandit, S., Chakrabarti, S., Banerjee, S., Nandini, P., Seal, T., 2017. Evaluation of Cynodon dactylon for wound healing activity. J. Ethnopharmacol. 197, 128-137. http://dx.doi.org/10.1016/j.jep.2016.07.065.

Bogdanović, M., Ilić, M., Živković, S., Sabovljević, A., Grubišić, D., Sabovljević, M., 2011. Comparative study on the effects of $\mathrm{NaCl}$ on selected moss and fern representatives. Aust. J. Bot. 59, 734-740. http://dx.doi.org/10.1071/BT11059.

Borer, C.H., Hamby, M.N., Hutchinson, L.H., 2012. Plant tolerance of a high calcium environment via foliar partitioning and sequestration. J. Arid Environ. 85, 128-131. http://dx.doi.org/10.1016/j.jaridenv.2012.06.004.

Boscaiu, M., Ballesteros, G., Naranjo, M.A., Vicente, O., Boira, H., 2011. Responses to salt stress in Juncus acutus and J. maritimus during seed germination and vegetative plant growth. Plant Biosyst. 145, 770-777. http://dx.doi.org/10.1080/11263504.2011. 628446.

Bouazza, L., Bodas, R., Boufennara, S., Bousseboua, H., Lopez, S., 2012. Nutritive evaluation of foliage from fodder trees and shrubs characteristic of Algerian arid and semi-arid areas. J. Anim. Feed Sci. 21, 521-536.

Boughalleb, N., Trabelsi, L., Harzallah-Skhiri, F., 2009. Antifungal activity from polar and non-polar extracts of some Chenopodiaceae wild species growing in Tunisia. Nat. Prod. Res. 23, 988-997. http://dx.doi.org/10.1080/14786410802168494.

Boulaaba, M., Tsolmon, S., Ksouri, R., Han, J., 2013. Anticancer effect of Tamarix gallica extracts on human colon cancer cells involves Erk1/2 and p38 action on G 2/M cell cycle arrest. Cytotechnology 65, 927-936. http://dx.doi.org/10.1007/s10616-0139564-4.

Boulaaba, M., Snoussi, M., Saada, M., Mkadmini, K., Smaoui, A., Abdelly, C., Ksouri, R., 2015. Antimicrobial activities and phytochemical analysis of Tamarix gallica extracts. Ind. Crop. Prod. 76, 1114-1122. http://dx.doi.org/10.1016/j.indcrop.2015.08.020.

Bournine, L., Bensalem, S., Wauters, J.-N., Iguer-Ouada, M., Maiza-Benabdesselam, F., Bedjou, F., Castronovo, V., Bellahcène, A., Tits, M., Frédérich, M., 2013. Identification and quantification of the main active anticancer alkaloids from the root of Glaucium flavum. Int. J. Mol. Sci. 14, 23533-23544. http://dx.doi.org/10.3390/ ijms141223533.

Cabo, J., Cabo, M., Jimenez, J., Zarzuelo, A., 1987. A pharmacological study of Glaucium flavum Crantz. II: central bervous system. Phyther. Res. 1, 169-172.

Cabo, J., Cabo, P., Jimenez, J., Zarzuelo, A., 1988. Glaucium flavum Crantz. Part V: hypoglycemic activity of the aqueous extract. Phyther. Res. 2, 198-200.

Cambrollé, J., Redondo-Gómez, S., Mateos-Naranjo, E., Luque, T., Figueroa, M.E., 2011 Physiological responses to salinity in the yellow-horned poppy, Glaucium flavum. Plant Physiol. Biochem. 49, 186-194. http://dx.doi.org/10.1016/j.plaphy.2010.11. 008

Chen, S., Ju, M., Luo, Y., Chen, Z., Zhao, C., Zhou, Y., 2013. Hepatoprotective and antioxidant activities of the aqueous extract from the rhizome of Phragmites australis. Z. Naturforsch. 68, 439-444.

Choi, S.-E., Yoon, J.-H., Choi, H.-K., Lee, M.-W., 2009. Phenolic compounds from the root of Phragmites communis. Chem. Nat. Compd. 45, 893-895.

Cooper, M.R., Johnson, W.A. (Eds.), 1998. Poisonous Plants and Fungi in Britain: Animal and Human Poisoning, second ed. CABI, London.

Daskalova, E., Iskrenova, E., Kiryakov, H., Evstatieva, L., 1988. Minor alkaloids of Glaucium flavum. Phytochemistry 27, 953-955.

Davy, A.J., Scott, R., Cordazzo, C.V., 2006. Biological flora of the british Isles: Cakile maritima Scop. J. Ecol. 94, 695-711. http://dx.doi.org/10.1111/j.1365-2745.2006. 01131.x.

de Silva, H.A., Saparamadu, P.A.M., Thabrew, M.I., Pathmeswaran, A., Fonseka, M.M.D., de Silva, H.J., 2003. Liv. 52 in alcoholic liver disease: a prospective, controlled trial. J. Ethnopharmacol. 84, 47-50.

Debez, A., Saadaoui, D., Ramani, B., Ouerghi, Z., Koyro, H., Huchzermeyer, B., Abdelly, C., 2006. Leaf $\mathrm{H}+$-ATPase activity and photosynthetic capacity of Cakile maritima under increasing salinity. Environ. Exp. Bot. 57, 285-295. http://dx.doi.org/10. 1016/j.envexpbot.2005.06.009.

Doncheva, T., Doycheva, I., Philipov, S., 2016. Alkaloid chemotypes of Glaucium flavum (Papaveraceae) from Bulgaria. Biochem. Syst. Ecol. 68, 1-5. http://dx.doi.org/10. 1016/j.bse.2016.06.014.

Durdević, L., Mitrović, M., Pavlović, P., Bojović, S., Jarić, S., Oberan, L., Gajić, G., Kostić, O., 2007. Total phenolics and phenolic acids content in leaves, rhizomes and rhizosphere soil under Ceterach officinarum D.C., Asplenium trichomanes L. and A. adiantum nigrum L. in the Gorge Sićevo (Serbia), vol 26. Ekol, Bratislava, pp. 164-173.

El-Aasr, M., Kabbash, A., El-Seoud, K.A.A., Al-Madboly, L.A., Ikeda, T., 2016. Antimicrobial and immunomodulatory activities of flavonol glycosides isolated from Atriplex halimus L. herb. J. Pharm. Sci. Res. 8, 1159-1168.

El-Shamy, A.I., Abdel-razek, A.F., Nassar, M.I., 2015. Phytochemical review of Juncus L. genus (Fam. Juncaceae). Arab. J. Chem. 8, 614-623. http://dx.doi.org/10.1016/j. arabjc.2012.07.007.

El-Shatnawi, M.K.J., Mohawesh, Y.M., 2000. Seasonal chemical composition of saltbush in semiarid grasslands of Jordan. J. Range Manag. 53, 211-214.

Fountoulakis, M.S., Daskalakis, G., Papadaki, A., 2017. Use of halophytes in pilot-scale horizontal flow constructed wetland treating domestic wastewater. Environ. Sci. Pollut. Res. 24, 16682-16689. http://dx.doi.org/10.1007/s11356-017-9295-8.

Froissard, D., Rapior, S., Bessière, J.-M., Buatois, B., Fruchier, A., Sol, V., Fons, F., 2015. Asplenioideae species as a reservoir of volatile organic compounds with potential therapeutic properties. Nat. Prod. Commun. 10, 1079-1083.

Fruet, A.C., Seito, L.N., Rall, V.L.M., Di Stasi, L.C., 2012. Dietary intervention with narrow-leaved cattail rhizome flour (Typha angustifolia L.) prevents intestinal inflammation in the trinitrobenzenesulphonic acid model of rat colitis. BMC Compl. Altern. Med. 12, 1-11. http://dx.doi.org/10.1186/1472-6882-12-62.

Gao, H.-X., Ding, A.-W., Tang, Y.-P., Zhang, X., Duan, J.-A., 2009. Chemical constituents from the rhizomas of Phragmites communis. Chin. J. Nat. Med. 7, 196-198. http://dx. doi.org/10.3724/SP.

Gil, R., Lull, C., Boscaiu, M., Lidón, A., Vicente, O., 2011. Soluble carbohydrates as osmolytes in several halophytes from a Mediterranean salt marsh. Not. Bot. Horti Agrobot. Cluj-Napoca 39, 9-17.

González-Tejero, M.R., Casares-Porcel, M., Sánchez-Rojas, C.P., Ramiro-Gutiérrez, J.M., Molero-Mesa, J., Pieroni, A., Giusti, M.E., Censorii, E., de Pasquale, C., Della, A., Paraskeva-Hadijchambi, D., Hadjichambis, A., Houmani, Z., El-Demerdash, M., ElZayat, M., Hmamouchi, M., ElJohrig, S., 2008. Medicinal plants in the Mediterranean area: synthesis of the results of the project Rubia. J. Ethnopharmacol. 116, 341-357. http://dx.doi.org/10.1016/j.jep.2007.11.045.

Grace, J.B., Harrison, J.S., 1986. The Biology of Canadian weeds. 73. Typha latifulia L., Typha angustifolia L. and Typha xglauca Godr. Can. J. Plant Sci. 66, 361-379.

Grieve, C., Poss, J., Grattan, S., Shouse, P., Lieth, J., Zeng, L., 2005. Productivity and mineral nutrition of Limonium species irrigated with saline wastewaters. Hortscience 40, 654-658.

Guarrera, P., Lucchese, F., Medori, S., 2008. Ethnophytotherapeutical research in the high Molise region (Central-Southern Italy). J. Ethnobiol. Ethnomed. 4, 1-11. http://dx. doi.org/10.1186/1746-4269-4-7. 
Gurunathan, S., 2015. Journal of Industrial and Engineering Chemistry Biologically synthesized silver nanoparticles enhances antibiotic activity against Gram-negative bacteria. J. Ind. Eng. Chem. 29, 217-226.

Hadjiakhoondi, F., Ostad, S., Khanavi, M., Hadjiakhoondi, A.B.F., Salarytabar, A., 2013. Cytotoxicity of two species of Glaucium from Iran. J. Med. Plants 11, 85-92.

Haloui, M., Louedec, L., Michel, J., 2000. Experimental diuretic effects of Rosmarinus officinalis and Centaurium erythraea. J. Ethnopharmacol. 71, 465-472.

Hameed, M., Ashraf, M., 2008. Physiological and biochemical adaptations of Cynodon dactylon (L.) Pers. from the Salt Range (Pakistan) to salinity stress. Flora 203 , 683-694. http://dx.doi.org/10.1016/j.flora.2007.11.005.

Hammad, I., Qari, S.H., 2010. Genetic diversity among Zygophyllum (Zygophyllaceae) populations based on RAPD analysis. Genet. Mol. Res. 9, 2412-2420. http://dx.doi. org/10.4238/vol9-4gmr1144.

Hammiche, V., Maiza, K., 2006. Traditional medicine in central Sahara: pharmacopoeia of tassili N' ajjer. J. Ethnopharmacol. 105, 358-367. http://dx.doi.org/10.1016/j jep.2005.11.028.

Hamza, N., Berke, B., Cheze, C., Le, R., Lassalle, R., Agli, A., Robinson, P., Gin, H., Moore, N., 2011. Treatment of high fat diet induced type 2 diabetes in C57BL/6J mice by two medicinal plants used in traditional treatment of diabetes in the east of Algeria. J. Ethnopharmacol. 133, 931-933. http://dx.doi.org/10.1016/j.jep.2010.11.019.

Hanlidou, E., Karousou, R., Kleftoyanni, V., Kokkini, S., 2004. The herbal market of Thessaloniki (N Greece) and its relation to the ethnobotanical tradition. J. Ethnopharmacol. 91, 281-299. http://dx.doi.org/10.1016/j.jep.2004.01.007.

Hassan, M. Al, Chaura, J., Donat-Torres, P., Boscaiu, M., Oscar, V., 2017a. Antioxidant responses under salinity and drought in three closely related wild monocots with different ecological optima. AoB Plants 9http://dx.doi.org/10.1093/aobpla/plx009. plx009.

Hassan, M. Al, Estrelles, E., Soriano, P., Boscaiu, M., Vicente, O., 2017b. Unraveling salt tolerance mechanisms in halophytes: a comparative study on four Mediterranean Limonium species with different geographic distribution patterns. Front. Plant Sci. 8, 1-21. http://dx.doi.org/10.3389/fpls.2017.01438.

Hmidene, A. Ben, Hanaki, M., Murakami, K., Irie, K., Isoda, H., Shigemori, H., 2017. Inhibitory activities of antioxidant flavonoids from Tamarix gallica on amyloid aggregation related to Alzheimer's and type 2 diabetes diseases. Biol. Pharm. Bull. 40, $238-241$

Horowitz, M., 1996. Bermudagrass (Cynodon dactylon): a history of the weed and its control in Israel. Phytoparasitica 24 305-302.

Huseini, H.F., Alavian, S.M., Heshmat, R., Heydari, M.R., Abolmaali, K., 2005. The efficacy of Liv-52 on liver cirrhotic patients : a randomized, double-blind, placebo-controlled first approach. Phytomedicine 12, 619-624. http://dx.doi.org/10.1016/j. phymed.2004.10.003.

Hussein, S.A., 2004a. Phenolic sodium sulphates of Frankenia laevis L. Pharmazie 59, 304-308.

Hussein, S.A., 2004b. Flavonoid and methoxyellagic acid sodium sulphates from Frankenia laevis L. Pharmazie 59, 484-487.

Iranshahi, M., 2012. A review of volatile sulfur-containing compounds from terrestrial plants: biosynthesis, distribution and analytical methods. J. Essent. Oil Res. 24, 393-434. http://dx.doi.org/10.1080/10412905.2012.692918.

Jananie, R.K., Priya, V., Vijayalakshmi, K., 2011. Determination of bioactive components of Cynodon dactylon by GC-MS analysis. New York Sci. J. 4, 16-20.

Jdey, A., Falleh, H., Ben Jannet, S., Mkadmini Hammi, K., Dauvergne, X., Ksouri, R., Magné, C., 2017. Phytochemical investigation and antioxidant, antibacterial and anti-tyrosinase performances of six medicinal halophytes. South Afr. J. Bot. 112, 508-514. http://dx.doi.org/10.1016/j.sajb.2017.05.016.

Jemia, M. Ben, Kchouk, M.E., Senatore, F., Autore, G., Marzocco, S., Feo, V. De, Bruno, M., 2013. Antiproliferative activity of hexane extract from Tunisian Cistus libanotis, Cistus monspeliensis and Cistus villosus. Chem. Cent. J. 7, 1-7.

Kabbash, A., Shoeib, N., 2012. Chemical and biological investigation of some secondary metabolites in Atriplex halimus growing in Egypt. Nat. Prod. Commun. 7, 1465-1468.

Kashyap, D., Sharma, A., Singh, H., Sak, K., Punia, S., Mukherjee, T.K., 2017. Kaempferol - a dietary anticancer molecule with multiple mechanisms of action : recent trends and advancements. J. Funct. Foods 30, 203-219. http://dx.doi.org/10.1016/j.jff. 2017.01.022.

Kausch, A.P., Seago, J.L.J., Marsh, L.C., 1981. Changes in starch distribution in the overwintering organs of Typha latifolia (Typhaceae). Am. J. Bot. 68, 877-880.

Kchaou, M., Salah, H. Ben, Mhiri, R., Allouche, N., 2016. Anti-oxidant and anti-acetylcholinesterase activities of Zygophyllum album. Bangladesh J. Pharmacol. 11, 54-62. http://dx.doi.org/10.3329/bjp.v11i1.25463.

Kiviat, E., Hamilton, E., 2001. Phragmites use by native North Americans. Aquat. Bot. 69, 341-357.

Kristanc, L., Kreft, S., 2016. European medicinal and edible plants associated with subacute and chronic toxicity part II: plants with hepato-, neuro-, nephro- and immunotoxic effects. Food Chem. Toxicol. 92, 38-49.

Ksouri, R., Megdiche, W., Debez, A., Falleh, H., 2007. Salinity effects on polyphenol content and antioxidant activities in leaves of the halophyte Cakile maritima. Plan Physiol. Biochem. 45, 244-249. http://dx.doi.org/10.1016/j.plaphy.2007.02.001.

Ksouri, R., Megdiche, W., Falleh, H., Trabelsi, N., Boulaaba, M., Smaoui, A., Abdelly, C., 2008. Influence of biological, environmental and technical factors on phenolic content and antioxidant activities of Tunisian halophytes. C. R. Biol. 331, 865-873. http://dx.doi.org/10.1016/j.crvi.2008.07.024.

Ksouri, R., Falleh, H., Megdiche, W., Trabelsi, N., Mhamdi, B., Chaieb, K., Bakrouf, A., Magné, C., Abdelly, C., 2009. Antioxidant and antimicrobial activities of the edible medicinal halophyte Tamarix gallica L. and related polyphenolic constituents. Food Chem. Toxicol. 47, 2083-2091. http://dx.doi.org/10.1016/j.fct.2009.05.040.

Ksouri, R., Ksouri, W.M., Jallali, I., Debez, A., Magné, C., Hiroko, I., Abdelly, C., 2012. Medicinal halophytes: potent source of health promoting biomolecules with medical, nutraceutical and food applications. Crit. Rev. Biotechnol. 32, 289-326. http://dx doi.org/10.3109/07388551.2011.630647.

Ksouri, W.M., Medini, F., Mkadmini, K., Legault, J., Magné, C., Abdelly, C., Ksouri, R., 2013. LC-ESI-TOF-MS identification of bioactive secondary metabolites involved in the antioxidant, anti-inflammatory and anticancer activities of the edible halophyte Zygophyllum album Desf. Food Chem. 139, 1073-1080. http://dx.doi.org/10.1016/j. foodchem.2013.01.047.

Lefahal, M., Zaabat, N., Djarri, L., Benahmed, M., Medjroubi, K., Laouer, H., Akkal, S., 2017. Evaluation of the antioxidant activity of extracts and flavonoids obtained from Bunium alpinum Waldst. \& Kit. (Apiaceae). Curr. Issues Pharm. Med. Sci. 30, 5-8. http://dx.doi.org/10.1515/cipms-2017-0001.

Li, A., Li, S., Li, H., Xu, D., Xu, X., Chen, F., 2014. Total phenolic contents and antioxidant capacities of 51 edible and wild flowers. J. Funct. Foods 6, 319-330.

Li, B.-J., Liu, Y., Gu, A.-T., Wang, F., 2017. Chemical constituents of Cynodon dactylon. Chin. Tradit. Herb. Drugs 48, 62-66.

Li Rosi, A., Di Gregorio, R., Toscano, S., Romano, D., 2010. Native Mediterranean Cistus species for urban green areas. Acta Hortic. 881, 577-580.

Lidder, S., Dargan, P.I., Sexton, M., Button, J., Ramsey, J., Holt, D.W., Wood, D.M., 2008. Cardiovascular toxicity associated with recreational use of diphenylprolinol ( diphenyl-2-pyrrolidinemethanol. J. Med. Toxicol. 4, 167-169.

Lissner, J., Schierup, H.-H., 1997. Effects of salinity on the growth of Phragmites australis. Aquat. Bot. 55, 247-260. http://dx.doi.org/10.1016/S0304-3770(96)01085-6.

Loizzo, M.R., Jemia, M. Ben, Senatore, F., Bruno, M., Menichini, F., Tundis, R., 2013. Chemistry and functional properties in prevention of neurodegenerative disorders of five Cistus species essential oils. Food Chem. Toxicol. 59, 586-594. http://dx.doi. org/10.1016/j.fct.2013.06.040.

Londonkar, R.L., Kattegouga, U.M., Shivsharanappa, K., Hanchinalmath, J.V., 2013 Phytochemical screening and in vitro antimicrobial activity of Typha angustifolia Linn leaves extract against pathogenic gram negative micro organisms. 6, 6-9.

Lopes, A., Rodrigues, M.J., Pereira, C., Oliveira, M., Barreira, L., Varela, J., Trampetti, F., Custódio, L., 2016. Natural products from extreme marine environments: searching for potential industrial uses within extremophile plants. Ind. Crop. Prod. 94, 299-307. http://dx.doi.org/10.1016/j.indcrop.2016.08.040.

López-Miranda, J.L., Vázquez, M., Fletes, N., Esparza, R., Rosas, G., 2016. Biosynthesis of silver nanoparticles using a Tamarix gallica leaf extract and their antibacterial activity. Mater. Lett. 176, 285-289. http://dx.doi.org/10.1016/j.matlet.2016.04.126.

Mahjoub, M., Mighri, Z., Chriaa, J., Daami, M., Saidana, D., Helal, A.N., 2010. Studies of the essential oil composition, antibacterial and antifungal activity profiles of Frankenia laevis L. from Tunisia. J. Essent. Oil Res. 22, 349-353.

Mal, T.K., Narine, L., 2004. The biology of Canadian weeds. 129. Phragmites australis (Cav.) Trin. ex Steud. Can. J. Plant Sci. 84, 365-396.

Manning, J.C., Helme, N.A., 2014. Frankenia fruticosa (Frankeniaceae), a new dwarf shrub from the Knersvlakte, Western Cape. South Afr. J. Bot. 91, 84-87. http://dx.doi.org/ 10.1016/j.sajb.2014.01.001.

Marasini, B.P., Baral, P., Aryal, P., Ghimire, K.R., Neupane, S., Dahal, N., Singh, A., Ghimire, L., Shrestha, K., 2015. Evaluation of antibacterial activity of some traditionally used medicinal plants against human pathogenic bacteria. BioMed Res. Int. 1-6.

Maria, P., Salerno, G., Caneva, G., 2005. Folk phytotherapeutical plants from Maratea area (Basilicata, Italy). J. Ethnopharmacol. 99, 367-378. http://dx.doi.org/10.1016/ j.jep.2005.01.039.

Mateos-Naranjo, E., Andrades-Moreno, L., Cambrollé, J., Perez-Martin, A., 2013. Assessing the effect of copper on growth, copper accumulation and physiological responses of grazing species Atriplex halimus: ecotoxicological implications. Ecotoxicol. Environ. Saf. 90, 136-142. http://dx.doi.org/10.1016/j.ecoenv.2012.12. 020 .

McMillan, C., 1959. Salt tolerance within a Typha population. Am. J. Bot. 46, 521-526.

Megdiche, W., Passaquet, C., Zourrig, W., Zuily, Y., Abdelly, C., 2009. Molecular cloning and characterization of novel cystatin gene in leaves Cakile maritima halophyte. J. Plant Physiol. 166, 739-749. http://dx.doi.org/10.1016/j.jplph.2008.09.012.

Menale, B., Muoio, R., 2014. Use of medicinal plants in the south-eastern area of the partenio regional park (Campania, southern Italy). J. Ethnopharmacol. 153, 297-307. http://dx.doi.org/10.1016/j.jep.2014.02.039.

Meot-Duros, L., Le Floch, G., Magné, C., 2008. Radical scavenging, antioxidant and antimicrobial activities of halophytic species. J. Ethnopharmacol. 116, 258-262. http:// dx.doi.org/10.1016/j.jep.2007.11.024.

Mišić, D., Šiler, B., Filipović, B., Popović, Z., Živković, S., Cvetić, T., Mijović, A., 2009. Rapid in vitro selection of salt-tolerant genotypes of the potentially medicinal plant Centaurium maritimum (L.) Fritsch. Arch. Biol. Sci. 61, 57-69. http://dx.doi.org/10. 2298/ABS0901057M.

Mišić, D., Šiler, B., Živković, J.N., Simonović, A., Maksimović, V., Budimir, S., Janošević, D., Duričković, M., Nikolić, M., 2012. Contribution of inorganic cations and organic compounds to osmotic adjustment in root cultures of two Centaurium species differing in tolerance to salt stress. Plant Cell Tissue Organ Cult. 108, 389-400. http:// dx.doi.org/10.1007/s11240-011-0050-4.

Mišić, D., Šiler, B., Skorić, M., Djurickovic, M.S., Živković, J.N., Jovanović, V., Giba, Z., 2013. Secoiridoid glycosides production by Centaurium maritimum (L.) Fritch hairy root cultures in temporary immersion bioreactor. Process Biochem. 48, 1587-1591.

Mnafgui, K., Kchaou, M., Hamden, K., Derbali, F., Slama, S., Nasri, M., Salah, H. Ben, Allouche, N., Elfeki, A., 2014. Inhibition of carbohydrate and lipid digestive enzymes activities by Zygophyllum album extracts: effect on blood and pancreas inflammatory biomarkers in alloxan-induced diabetic rats. J. Physiol. Biochem. 70, 93-106. http:// dx.doi.org/10.1007/s13105-013-0284-1.

Molina, M., Pardo-de-Santayana, M., García, E., Aceituno-Mata, L., Morales, R., Tardío, J., 2012. Exploring the potential of wild food resources in the Mediterranean region: natural yield and gathering pressure of the wild asparagus (Asparagus acutifolius L.). 
Spanish J. Agric. Res. 10, 1090. http://dx.doi.org/10.5424/sjar/2012104-3050.

Montesano, V., Negro, D., Sarli, G., Lisi, A. De, Laghetti, G., Hammer, K., 2012. Notes about the uses of plants by one of the last healers in the Basilicata Region (South Italy). J. Ethnobiol. Ethnomed. 8, 1-15.

Moustafa, A.M.Y., Khodair, A.I., Hammouda, F.M., Husseiny, H.A., 2007. Phytochemical and toxicological studies of Zygophyllum album L.f. J. Pharmacol. Toxicol. 2, 220-237.

Mukherjee, P.K., Ponnusankar, S., Pandit, S., Hazam, P.K., Ahmmed, M., 2011. Botanicals as medicinal food and their effects on drug metabolizing enzymes. Food Chem. Toxicol. 49, 3142-3153. http://dx.doi.org/10.1016/j.fct.2011.09.015.

Muthukrishnan, S.D., Kaliyaperumal, A., Subramaniyan, A., 2015. Identification and determination of flavonoids, carotenoids and chlorophyll concentration in Cynodon dactylon (L.) by HPLC analysis. Nat. Prod. Res. 29, 785-790. http://dx.doi.org/10. 1080/14786419.2014.986125.

Naveed, S.A., Reddy, M.S., Kumar, C.P., Suhasini, B., Dontamalla, Sudheerkumar, 2015. Anti-hyperlipidemic activity of Tamarix gallica extracts in Triton X-100 induced hyperlipidemic rats. Int. J. Pharm. Technol. 6, 7880-7895.

Neves, J.M., Matos, C., Moutinho, C., Queiroz, G., Gomes, L.R., 2009. Ethnopharmacological notes about ancient uses of medicinal plants in Trás-os-Montes (northern of Portugal). J. Ethnopharmacol. 124, 270-283. http://dx.doi.org/10. 1016/j.jep.2009.04.041.

Nicoletti, M., Toniolo, C., Venditti, A., Bruno, M., Ben Jemia, M., 2015. Antioxidant activity and chemical composition of three Tunisian Cistus: Cistus monspeliensis, Cistus villosus and Cistus libanotis. Nat. Prod. Res. 29, 223-230.

Och, A., Szewczyk, K., Pecio, Ł., Stochmal, A., Za, D., Bogucka-kocka, A., 2017. UPLCMS/MS profile of alkaloids with cytotoxic properties of selected medicinal plants of the berberidaceae and Papaveraceae families. Oxid. Med. Cell. Longev Article ID, 7.

Orallo, F., Alzueta, A.F., Campos-toimil, M., Calleja, J.M., 1995. Study of the in vivo and in vitro cardiovascular effects of $(+)$-glaucine and $\mathrm{N}$-carbethoxysecoglaucine in rats. Br. J. Pharmacol. 114, 1419-1427.

Ozcan, T., 2014. Fatty acid composition of seed oils in some sand dune vegetation species from Turkey. Chem. Nat. Compd. 50, 804-809. http://dx.doi.org/10.1007/s10600014-1088-4.

Palombo, E.A., Semple, S.J., 2001. Antibacterial activity of traditional Australian medicinal plants. J. Ethnopharmacol. 77, 151-157.

Panta, S., Flowers, T., Lane, P., Doyle, R., Haros, G., Shabala, S., 2014. Halophyte agriculture: success stories. Environ. Exp. Bot. 107, 71-83.

Papaefthimiou, D., Papanikolaou, A., Falara, V., Givanoudi, S., 2014. Genus Cistus : a model for exploring labdane-type diterpenes' biosynthesis and a natural source of high value products with biological, aromatic, and pharmacological properties. Front. Chem. 2, 1-19. http://dx.doi.org/10.3389/fchem.2014.00035.

Passalacqua, N.G., Guarrera, P.M., Fine, G. De, 2007. Contribution to the knowledge of the folk plant medicine in Calabria region (Southern Italy). Fitoterapia 78, 52-68. http://dx.doi.org/10.1016/j.fitote.2006.07.005.

Patankar, S.B., Mujumdar, A.M., Sane, R.T., Remya, U., 2015. Evaluation of safety profiles of anuradha oil-an herbal wound healing formulation in laboratory animals. Int. J. Pharm. Pharm. Sci. 7, 278-282.

Pérez-Esteban, J., Escolástico, C., Ruiz-Fernández, J., Masaguer, A., Moliner, A., 2013. Bioavailability and extraction of heavy metals from contaminated soil by Atriplex halimus. Environ. Exp. Bot. 88, 53-59. http://dx.doi.org/10.1016/j.envexpbot.2011. 12.003.

Pessarakli, M., 2015. Using Bermudagrass (Cynodon dactylon L.) in urban desert landscaping and as a forage crop for sustainable agriculture in arid regions and combating desertification. Int. J. Water Resour. Arid Environ. 4, 8-14.

Petitto, V., Serafini, M., Gallo, F.R., Multari, G., Nicoletti, M., 2010. Alkaloids from Glaucium flavum from Sardinia. Nat. Prod. Res. 24, 1033-1035. http://dx.doi.org/10. 1080/14786410902904418.

Petlevski, R., Hadžija, M., Slijepčević, M., Juretić, D., 2008. Toxicological assessment of P-9801091 plant mixture extract after chronic administration in CBA/HZg mice - a biochemical and histological study. Coll. Antropol. 32, 577-581.

Pieroni, A., 2017. Traditional uses of wild food plants, medicinal plants, and domestic remedies in Albanian, Aromanian and Macedonian villages in South-Eastern Albania. J. Herb. Med. 9, 81-90. http://dx.doi.org/10.1016/j.hermed.2017.05.001.

Pieroni, A., Quave, C.L., Santoro, R.F., 2004. Folk pharmaceutical knowledge in the territory of the Dolomiti Lucane, inland southern Italy. J. Ethnopharmacol. 95, 373-384. http://dx.doi.org/10.1016/j.jep.2004.08.012.

Polat, R., Satil, F., 2012. An ethnobotanical survey of medicinal plants in Edremit Gulf (Balikesir - Turkey). J. Ethnopharmacol. 139, 626-641. http://dx.doi.org/10.1016/j jep.2011.12.004.

Qin, F., Sun, H., 2005. Immunosuppressive activity of Pollen Typhae ethanol extract on the immune responses in mice. J. Ethnopharmacol. 102, 424-429. http://dx.doi.org/ 10.1016/j.jep.2005.06.027.

Radwan, H., Shams, K.A., Soliman, A.M., 2008. Investigation of the glucosinolates and lipids constituents of Cakile maritima (Scope) growing in Egypt and their biological activity. Res. J. Med. Med. Sci. 3, 182-187.

Rai, P.K., Jaiswal, D., Rai, D.K., Sharma, B., Watal, G., 2010. Antioxidant potential of oral feeding of Cynodon dactylon extract on diabetes-induced oxidative stress. J. Food Biochem. 34, 78-92. http://dx.doi.org/10.1111/j.1745-4514.2009.00265.x.

Raman, S.B., Rathinasabapathi, B., 2003. $\beta$-alanine N -methyltransferase of Limonium latifolium. cDNA cloning and functional expression of a novel $\mathrm{N}$ - methyltransferase implicated in the synthesis of the osmoprotectant $\beta$-alanine betaine. J. Agric. Food Chem. 132, 1642-1651. http://dx.doi.org/10.1104/pp.103.020453.mulated.

Rivoal, J., Hanson, A.D., 1994. Choline-O-Sulfate biosynthesis in plants. Identification and partial characterization characterization of a salinity-inducible choline sulfotransferase from species of Limonium (Plumbaginaceae). Plant Physiol. 106, $1187-1193$

Rodrigues, M.J., Gangadhar, K.N., Vizetto-Duarte, C., Wubshet, S.G., Nyberg, N.T.,
Barreira, L., Varela, J., Custódio, L. sa, 2014. Maritime halophyte species from southern Portugal as sources of bioactive molecules. Mar. Drugs 12, 2228-2244. http://dx.doi.org/10.3390/md12042228.

Rodrigues, M.J., Gangadhar, K.N., Zengin, G., Mollica, A., Varela, J., Barreira, L., Custódio, L., 2017. Juncaceae species as sources of innovative bioactive compounds for the food industry: in vitro antioxidant activity, neuroprotective properties and in silico studies. Food Chem. Toxicol. 107, 590-596. http://dx.doi.org/10.1016/j.fct. 2017.04.006.

Ross, S.A., 1984. Myricetin-3 '-methyl ether-7-glucoside from Limonlum sinuatum. J. Nat. Prod. 4, 862-864. http://dx.doi.org/10.1021/np50035a019.

Saïdana, D., Mahjoub, M., Mighri, Z., Chriaa, J., Daamiand, M., Helal, A., 2010. Studies of the essential oil composition, antibacterial and antifungal activity profiles of Frankenia laevis L. from Tunisia. J. Essent. Oil Res. 22, 349-353.

Sánchez-Mata, M.C., Loera, R.D.C., Morales, P., Fernández-Ruiz, V., Cámara, M., Marqués, C.D., Pardo-de-Santayana, M., Tardío, J., 2012. Wild vegetables of the Mediterranean area as valuable sources of bioactive compounds. Genet. Resour. Crop Evol. 59, 431-443. http://dx.doi.org/10.1007/s10722-011-9693-6.

Sassi, A. Ben, Harzallah-skhiri, F., Aouni, M., 2017. Investigation of some medicinal plants from Tunisia for antimicrobial activities. Pharm. Biol. 45, 421-428. http://dx. doi.org/10.1080/13880200701215406.

Sayah, K., Chemlal, L., Marmouzi, I., Jemli, M. El, Cherrah, Y., El, M., Faouzi, A., 2017. In vivo anti-inflammatory and analgesic activities of Cistus salviifolius (L.) and Cistus monspeliensis (L.) aqueous extracts. South Afr. J. Bot. 113, 160-163. http://dx.doi. org/10.1016/j.sajb.2017.08.015.

Sehrawat, A., Sultana, S., 2006. Evaluation of possible mechanisms of protective role of Tamarix gallica against DEN initiated and 2-AAF promoted hepatocarcinogenesis in male Wistar rats. Life Sci. 79, 1456-1465. http://dx.doi.org/10.1016/j.lfs.2006.04. 009.

Shimoda, Y., Han, J., Kawada, K., Smaoui, A., Isoda, H., 2012. Metabolomics analysis of cistus monspeliensis leaf extract on energy metabolism activation in human intestinal cells. J. Biomed. Biotechnol. 7. http://dx.doi.org/10.1155/2012/428514.

Shode, F.O., Mahomed, A.S., Rogers, C.B., 2002. Typhaphthalide and typharin, two phenolic compounds from Typha capensis. Phytochemistry 61, 955-957.

Šiler, B., Živković, S., Banjanac, T., Cvetković, J., Živković, N.J., Ćirić, A., Soković, M., Mišić, D., 2014. Centauries as underestimated food additives: antioxidant and antimicrobial potential. Food Chem. 147, 367-376.

Sim, M.-O., Ham, J.R., Lee, M.-K., 2017. Young leaves of reed (Phragmites communis) suppress melanogenesis and oxidative stress in B16F10 melanoma cells. Biomed. Pharmacother. 93, 165-171. http://dx.doi.org/10.1016/j.biopha.2017.06.037.

Simopoulos, A.P., 2004. Omega-3 fatty acids and antioxidants in edible wild plants. Biol. Res. 37, 263-277. http://dx.doi.org/10.4067/S0716-97602004000200013.

Simopoulos, A.P., 2008. The importance of the omega-6/omega-3 fatty acid ratio in cardiovascular disease and other chronic diseases. Exp. Biol. Med. 233, 674-688.

Singh, S.K., Kesari, A.N., Gupta, R.K., Jaiswal, D., Watal, G., 2007. Assessment of antidiabetic potential of Cynodon dactylon extract in streptozotocin diabetic rats. J. Ethnopharmacol. 114, 174-179. http://dx.doi.org/10.1016/j.jep.2007.07.039.

Soraya, H., Moloudizargari, M., Aghajanshakeri, S., Javaherypour, S., Mokarizadeh, A., Hamedeyazdan, S., Esmaeli, H., Ghaleh, G., Mikaili, P., Garjani, A., 2015. Angiogenic effect of the aqueous extract of Cynodon dactylon on human umbilical vein endothelial cells and granulation tissue in rat. DARU J. Pharm. Sci. 23, 1-8. http://dx. doi.org/10.1186/s40199-015-0093-x.

Spasova, M., Philipov, S., Nikolaeva-glomb, L., Galabov, A.S., Milkova, T., 2008. Bioorganic \& medicinal chemistry cinnamoyl- and hydroxycinnamoyl amides of glaucine and their antioxidative and antiviral activities. Bioorg. Med. Chem. 16, 7457-7461. http://dx.doi.org/10.1016/j.bmc.2008.06.010.

Tagliati, C.A., Silva, R.P., Féres, C.A.O., Jorge, R.M., Rocha, O.A., Braga, F.C., 2008. Acute and chronic toxicological studies of the Brazilian phytopharmaceutical product Ierobina". Braz. J. Pharmacogn. 18, 676-682. http://dx.doi.org/10.1590/S0102 $695 X 2008000500006$.

Tahraoui, A., Israili, Z.H., Lyoussi, B., 2010. Acute and sub-chronic toxicity of a lyophilised aqueous extract of Centaurium erythraea in rodents. J. Ethnopharmacol. 132, 48-55. http://dx.doi.org/10.1016/j.jep.2010.07.038.

Tao, W.-W., Yang, N.-Y., Liu, L., Duan, J.-A., Wu, D.-K., Qian, D.-W., Tang, Y.-P., 2010. Fitoterapia Two new cerebrosides from the pollen of Typha angustifolia. Fitoterapia 81, 196-199. http://dx.doi.org/10.1016/j.

Terrones, A., Moreno, J., Agulló, J.C., Villar, J.L., Vicente, A., Alonso, M.Á., Juan, A., 2016. Influence of salinity and storage on germination of Tamarix taxa with contrasted ecological requirements. J. Arid Environ. 135, 17-21. http://dx.doi.org/10. 1016/j.jaridenv.2016.08.001.

Tigrine-Kordjani, N., Meklati, B.Y., Chemat, F., 2006. Analysis by gas chromatography mass spectrometry of the essential oil of Zygophyllum album L., an aromatic and medicinal plant growing in Algeria. Int. J. Aromather. 16, 187-191. http://dx.doi. org/10.1016/j.ijat.2006.09.008.

Tomas-Barberán, F.A., Iniesta-Sanmartin, E., Ferreres, F., Francisco, T.-L., TrowitzschKienast, W., Wray, V., 1990. Trans-coniferyl alcohol 4-O-Sulphate and flavonoid sulphates from some Tamarix species. Phytochemistry 29, 3050-3051.

Torrecillas, A., Rodríguez, P., Sánchez-Blanco, M.J., 2003. Comparison of growth, leaf water relations and gas exchange of Cistus albidus and C. monspeliensis plants irrigated with water of different $\mathrm{NaCl}$ salinity levels. Sci. Hortic. (Amst.) 97, 353-368.

Trichopoulou, A., Vasilopoulou, E., Hollman, P., Chamalides, C., Foufa, E., Kaloudis, T., Kromhout, D., Miskaki, P., Petrochilou, I., Poulima, E., Stafilakis, K., Theophilou, D., 2000. Nutritional composition and flavonoid content of edible wild greens and green pies: a potential rich source of antioxidant nutrients in the Mediterranean diet. Food Chem. 70, 319-323. http://dx.doi.org/10.1016/S0308-8146(00)00091-1.

Tuttolomondo, T., Licata, M., Leto, C., Savo, V., Bonsangue, G., Letizia, M., Venturella, G., La, S., 2014. Ethnobotanical investigation on wild medicinal plants in the monti 
sicani regional park (Sicily, Italy). J. Ethnopharmacol. 153, 568-586.

Umesh, M.K., Sanjeevkumar, C.B., Nayaka, H.B., Londonkar, R.L., 2014. Evaluation of in vitro anti-thrombolytic activity and cytotoxicity potential of Typha angustifolia 1 leaves extracts. Int. J. Pharm. Pharm. Sci. 6, 81-85.

Urfi, M., Mujahid, M., Badruddeen, Akhtar, J., Khalid, M., Khan, M., Usmani, A., 2016. Tamarix gallica: for traditional uses, phytochemical and pharmacological potentials. J. Chem. Pharm. Res. 8, 809-814.

Valentāo, P., Fernandes, E., Carvalho, F., Andrade, P., Seabra, R., Bastos, M., 2002. Antioxidative properties of cardoon (Cynara cardunculus L.) infusion against superoxide radical, hydroxyl radical, and hypochlorous acid. J. Agric. Food Chem. 50, 4989-4993. http://dx.doi.org/10.1021/jf020225o.

Van Den Heede, C., Pajarón, S., Pangua, E., Viane, R.L.L., 2004. Asplenium ceterach and A. octoploideum on the Canary islands (Aspleniaceae, pteridophyta). Am. Fern J. 94 81-111.

Vardavas, C.I., Majchrzak, D., Wagner, K.H., Elmadfa, I., Kafatos, A., 2006. The antioxidant and phylloquinone content of wildly grown greens in Crete. Food Chem. 99, 813-821. http://dx.doi.org/10.1016/j.foodchem.2005.08.057.

Varghese, A., Gavani, U., Abraham, S., Parambi, D., Sathianarayanan, Jose, A., 2009. Phytochemical screening and antimicrobial investigation of Typha angustifolia Linn. Int. J. Chem. Sci. 7, 1905-1910.

Viegi, L., Pieroni, A., Maria, P., Vangelisti, R., 2003. A review of plants used in folk veterinary medicine in Italy as basis for a databank. J. Ethnopharmacol. 89, 221-244. http://dx.doi.org/10.1016/j.jep.2003.08.003.

Vitali, F., Pennisi, G., Attaguile, G., Savoca, F., Vitali, F., Pennisi, G., Attaguile, G., Savoca, F., 2011. Antiproliferative and cytotoxic activity of extracts from Cistus incanus L. and Cistus monspeliensis L. on human prostate cell lines. Nat. Prod. Commun. 25, 188-202. http://dx.doi.org/10.1080/14786410802583148.

Walker, D.J., Lutts, S., Sánchez-garcía, M., Correal, E., 2014. Atriplex halimus L.: its biology and uses. J. Arid Environ. 100-101, 111-121. http://dx.doi.org/10.1016/j. jaridenv.2013.09.004.

Wiszniewska, M., Pałczyński, C., Krawczyk-Szulc, P., Wittczak, T., Cyran, A., WalusiakSkorupa, J., 2011. Occupational allergy to Limonium sinuatum - a case report. Int. J. Occup. Med. Environ. Health 24, 304-307.

Xu, D., Zheng, J., Zhou, Y., Li, Y., Li, S., Li, H., 2017. Ultrasound-assisted extraction of natural antioxidants from the flower of Limonium sinuatum: optimization and comparison with conventional methods. Food Chem. 217, 552-559.

Yadav, A., Nath, P., 2017. Anthelmintic effects and toxicity of Cynodon dactylon (L.) Pers. in rodent models. J. Intercult. Ethnopharmacol. 6, 407. http://dx.doi.org/10.5455/ jice.20170810024110.

Zarrouk, M., Almi, H. El, Youssef, N.B., Sleimi, N., Miled, D.B., Smaoui, A., Abdelly, C., 2003. Lipid composition of seeds of local halophytes: Cakile maritima, Zygophyllum album and Crithmum maritimum. In: Lieth, H., Mochtchenko, M. (Eds.), Cash Crop Halophytes: Recent Studies. Kluwer Academic Publishers, pp. 121-126. http://dx. doi.org/10.1007/978-94-017-0211-9.

Zhu, L., Zhang, D., Yuan, C., Shang, Y., Jiang, Y., Shu, G., 2017. Anti-Inflammatory \& antiviral effects of water-soluble crude extract from Phragmites australis in vitro. Pak. J. Pharm. Sci. 30, 1357-1362.

Živković, S., Popović, M., Dragišić-Maksimović, J., Momčilović, I., Grubišić, D., 2010. Dehydration-related changes of peroxidase and polyphenol oxidase activity in fronds of the resurrection fern Asplenium ceterach L. Arch. Biol. Sci. 62, 1071-1081. http:// dx.doi.org/10.2298/ABS1004071Z.

Đorđević, M., Mihailović, M., Arambašić Jovanović, J., Grdović, N., Uskoković, A., Tolić, A., Sinadinović, M., Rajić, J., Mišić, D., Šiler, B., Poznanović, G., Vidaković, M., Dinić, S., 2017. Centaurium erythraea methanol extract protects red blood cells from oxidative damage in streptozotocin-induced diabetic rats. J. Ethnopharmacol. 202, $172-183$. 